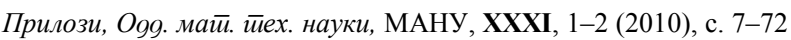
Contributions, Sec. Math. Tech. Sci., MANU, XXXI, 1-2 (2010), p. 7-72

ISSN 0351-3246

UDC: 003.322

\title{
COMPARATIVE ANALYSIS OF THE RESULTS OF DECIPHERING THE MIDDLE TEXT ON THE ROSETTA STONE
}

\author{
Tome Boševski, Aristotel Tentov
}

A b s t r a c t: In this text we present comparative analisys of the words and the expressions obtained after reading of complete middle text on the Rosetta Stone [15], by implementing our origtinal methodology presented in [12].

We have identified over 420 different words and expressions which preserve their meaning in contemporary Macedonian language and its dialects, but also they keep their meaning in archaic or contemporary in other Slavic languages. Identification and analysis of sentences and their structure will be subject of further researh.

Going further in depth with analysis and comparing our reading results of the middle text on the Rosetta Stone, [15], with well known previous results of reading so called ancient Greek text, presented in [4], [5], [6], and [9], one can easily conclude that two texts, so called demotic text, and so called ancient Greek text are identical only by their content of the pharaoh's orders. By all means, these two texts have different sentences structures, and different order of words within it. This fact is very logic and obvious in all cases where we compare two identical texts written in two different languages, and it is valid even today.

Based on our research we can further improve this conclusion in the direction that the pharaoh's decree on the middle text is written on the language of the Ancient Macedonians, with the script (signs) of the living masters in that period of Ancient Egypt. These language and script were state official language and official script in year $196 \mathrm{BC}$, after more than 100 years of the rulling of Ptolemaic Dynasty over Ancient Egypt. The language that we identified on the middle text on the Rosetta Stone defini- 
tely poses characteristics of a Slavic language. Many words that we identified in the middle text still exist in modern Slavic languages, or in their archaic forms, in respective Slavic language. Respectively, in lexical sense, we can identify that this language has very strong Slavic characteristics. This becomes more obvius after careful reading of presented multi-language dictionary.

Key words: Ancient Macedonians, language, script, syllabic nature

In this text, we present comparative analysis of the words and expressions after reading of the complete middle text on the Rosetta Stone, applying our methodology presented in [12].

We finish completely the reading of the so-called Demotic texts on the Rosetta Stone and on the Canopus Stele, explained in detail in [15], and [19]. Until now, in the so-called demotic texts on the Rosetta Stone and Canopus Stele, we were able to identify more then 430 different words, and expressions which have kept their meaning in some dialects of the Modern Macedonian Language, as well as in the archaic or in the modern form of the Slavic languages. Based on these research results, we can conclude with very high certainty that these two texts are written using Ancient Macedonian language and Ancient Macedonian script, i.e. with the official script and language of the state that had been ruled by them in $196 \mathrm{BC}$ for more than a century.

In accordance with our written material for the middle text on the Rosetta Stone, identification and analysis of the structure of sentences should be a subject of the future research.

Going deeply with analysis and comparing the results of our reading of the middle text, as well as the so called demotic text on the Canopus Stele, with appropriate known readings of the ancient Greek texts, presented in [4], [5], [6], and [9], we can conclude that the two texts are identical only by the contents of the pharaoh's orders. Within each text, a particular order of words is different, and the sentences in the compared texts have different structures, which is very logical and it is expected in each case when we are comparing two identical texts written in two different languages even today. In certain parts of texts our reading agrees within a single syllable, but in major part of the texts the sentences in the so-called Ancient-Greek texts are with reverse order of words compared with our reading of the Ancient-Macedonian texts. We must notify that when we are reading Ancient-Macedonian texts we obtain 
much more detailed and richer texts in comparison with existing readings of socalled Ancient-Greek texts. This fact leads to the conclusion that texts written with Ancient-Macedonian script using Ancient-Macedonian language are actually the original texts, and so-called Ancient-Greek texts are only a translation.

On the basis of the results from our research, we can further come to the conclusion that the Decree of the Pharaoh written on the middle text of the Rosetta Stone in original is scribed on the language of the Ancient-Macedonians, with the script of the living masters in that period, i.e. on the official language, and with the official script of the state with which in 196 B.C. the Ptolemaic dynasty ruled for more than one century. The language that we are discovering on the middle text on the Rosetta Stone, as well as on the so called Demotic text on the Canopus Stele is definitely incorporating characteristics of a Slavic language. Furthermore, every single word that we were able to identify in the text so far is also present in all modern Slavic languages as well, either in its archaic version or in the official version of the particular Slavic language. Consequently, in lexical sense, we can define this language as a language with very strong Slavic characteristics. This conclusion becomes more obvious after careful reading and analysis of the presented multi-language vocabulary.

In the Table 1 and Table 2 we present identified syllabic signs of the Ancient-Macedonian script, and their sounds values.

After that, we present the multi-language dictionary. 
Table $1-$ Табела 1

Asymmetric signs of the Ancient Macedonian (Demotic) Script and their wiring for sound

Асимейрични знаци на оревнойо макеgонско (gемойско) йисмо и нивно озвучување

\begin{tabular}{|c|c|c|c|c|c|c|c|c|c|}
\hline $\begin{array}{l}\text { No. } \\
\text { Бp. }\end{array}$ & $\begin{array}{c}\text { Vowels } \\
\text { Самогласки } \\
\text { Consonants } \\
\text { Согласки } \\
\end{array}$ & $\begin{array}{l}0 \\
\boldsymbol{\theta}\end{array}$ & $\stackrel{0}{\cap}$ & $\begin{array}{l}\mathrm{C} \\
\boldsymbol{L}\end{array}$ & ẹ & $\begin{array}{l}\mathrm{e} \\
\boldsymbol{E}\end{array}$ & $\stackrel{\mathrm{b}}{\mathbf{U}}$ & $\begin{array}{l}\mathrm{a} \\
-\end{array}$ & И \\
\hline 1. & $\mathbf{J}$ & $\mathrm{P}$ & 3 & & $C$ & ก & $\boldsymbol{0}$ & & \\
\hline 2 & $\mathbf{P}$ & a & 0 & & 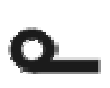 & 9 & 9 & & $\boldsymbol{\theta}$ \\
\hline 3. & Ѓ & & & & $c$ & 9 & & & 9 \\
\hline 4. & ж & & 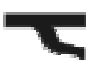 & & 2 & & & & \\
\hline 5. & 3 & & $c$ & & 2 & $\mathbf{v}$ & $c$ & 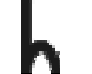 & 3 \\
\hline 6. & $\mathbf{S}$ & & 5 & & 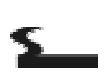 & & ? & $\mathbf{v}$ & \\
\hline 7. & $\mathbf{P}$ & & & & Lᄂ & & ב & & \\
\hline 8. & $\mathbf{T}$ & & & & 2 & & & & \\
\hline 9. & C & & & & $\angle$ & 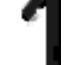 & $\mathbf{s}$ & 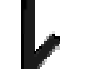 & $\boldsymbol{F}$ \\
\hline 10. & Ц & 13 & 7 & & $\angle$ & 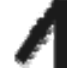 & 1 & $y$ & \\
\hline 11. & $\mathbf{Y}$ & 1 & $\Rightarrow$ & & $\angle$ & A & 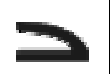 & $V$ & $=$ \\
\hline 12. & Ш & $\mathbf{P}$ & 5 & & $c$ & 7 & 0 & $y$ & $c$ \\
\hline 13. & Шт & $y$ & ? & A & 2 & 1 & 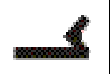 & 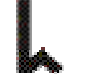 & \\
\hline
\end{tabular}


Table $2-$ Табела 2

Symmetrical and slanted signs of the Ancient Macedonian (Demotic) Script and their wiring for sound

Симетирични и накосени знаци на яревнотио макеgонско (gемойско) ииисмо и нивно озвучување

\begin{tabular}{|c|c|c|c|c|c|c|c|c|c|}
\hline $\begin{array}{l}\text { No } \\
\text { Бp }\end{array}$ & $\begin{array}{c}\text { Vowels } \\
\text { Самогласки } \\
\text { Consonants } \\
\text { Согласки }\end{array}$ & $\begin{array}{l}0 \\
\boldsymbol{8}\end{array}$ & $\begin{array}{l}0 \\
\cap\end{array}$ & $\begin{array}{c}y \\
L\end{array}$ & e & $\begin{array}{l}\mathrm{e} \\
\boldsymbol{E}\end{array}$ & $\mathcal{v}$ & $\begin{array}{l}a \\
-\end{array}$ & $\begin{array}{l}n \\
1\end{array}$ \\
\hline 1. & Б & & & & & & & & \\
\hline 2. & & & 4 & & & & & & \\
\hline 3. & $\Phi$ & & 1 & & & & & & \\
\hline 4. & $\mathbf{M}$ & & & & & & & & \\
\hline 5. & $\mathbf{X}$ & & & & & & 9 & & \\
\hline 6. & $\Gamma$ & & & & & & 7 & & \\
\hline 7. & Џ & & 3 & & & & 4 & & \\
\hline 8. & Д & & & & & & & & \\
\hline 9. & Л & & & & & & & & \\
\hline 10. & Љ & & & & & & & $\mathbf{A}$ & \\
\hline 11. & $\boldsymbol{\Omega}(\mathbf{P}) / \lambda$ & & & $A$ & & & & $\mathbf{A}$ & \\
\hline 12. & $\mathbf{H} 7$ & & & & & & & & \\
\hline 13. & њ $/$ & & & & & & & & \\
\hline 14. & $\mathbf{K}$ & & & & & & & & \\
\hline 15. & Ḱ & & & & & & & 2 & \\
\hline
\end{tabular}

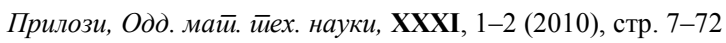




\section{COMPARATIVE SURVEY OF WORDS AND EXPRESSIONS FROM THE MIDDLE TEXT ON THE ROSETTA STONE}

КОМПАРАТИВЕН ПРЕГЛЕД НА ЗБОРОВИ И ИЗРАЗИ ОД СРЕДНИОТ ТЕКСТ НА КАМЕНОТ ОД РОЗЕТА

\begin{tabular}{|c|c|c|c|c|c|}
\hline & $\begin{array}{l}\text { The original } \\
\text { Оригинал } \\
\text { Оригинал }\end{array}$ & $\begin{array}{c}\text { Cyrillic transcription } \\
\text { Кирилична транскрипција } \\
\text { Кириличная транскрипция } \\
\leftarrow\end{array}$ & $\begin{array}{c}\text { Contemporary Macedonian } \\
\text { Современ македонски } \\
\text { Современный македонский } \\
\text { язык } \\
\rightarrow\end{array}$ & $\begin{array}{c}\text { English } \\
\text { Англиски } \\
\text { Англиский } \\
\rightarrow\end{array}$ & $\begin{array}{c}\text { Russian } \\
\text { Руски } \\
\text { Русский язык } \\
\rightarrow\end{array}$ \\
\hline \multicolumn{6}{|c|}{$\mathbf{A}$} \\
\hline 1. & & A & А, Прва, Врховна & A, First, Supreme & $\begin{array}{c}\text { А, Первая, самая } \\
\text { первая, Верхожная }\end{array}$ \\
\hline 2. & & aTA & Татко & Father & Отец \\
\hline 3. & & oTaTAaH & На таткото & Of the father & Отцовский \\
\hline 4. & & ооГоБ аЦеНаНА & Египетски бог Ананеца & $\begin{array}{l}\text { Egyptian God Ananetsa } \\
\text { (Greek name - Osiris) }\end{array}$ & Озирис \\
\hline 5. & & aЧеНаHА & $\begin{array}{c}\text { Египетска божица } \\
\text { Ананеча }\end{array}$ & $\begin{array}{c}\text { Egyptian Goddes } \\
\text { Ananetscha } \\
\text { (Greek name - Isis) }\end{array}$ & Изис \\
\hline 6. & 2 & ееТШАаН & $\begin{array}{c}\text { Нашата (штитеничка на } \\
\text { Врховната) }\end{array}$ & $\begin{array}{c}\text { Ours } \\
\text { (Protégé of a Supreme) }\end{array}$ & $\begin{array}{l}\text { Защитница } \\
\text { Верховной }\end{array}$ \\
\hline
\end{tabular}




\begin{tabular}{|c|c|c|c|c|c|}
\hline & $\begin{array}{l}\text { The original } \\
\text { Оригинал } \\
\text { Оригинал }\end{array}$ & $\begin{array}{c}\text { Cyrillic transcription } \\
\text { Кирилична транскрипција } \\
\text { Кириличная транскрипция } \\
\leftarrow\end{array}$ & $\begin{array}{c}\text { Contemporary Macedonian } \\
\text { Современ македонски } \\
\text { Современный македонский } \\
\text { язык } \\
\rightarrow\end{array}$ & $\begin{array}{c}\text { English } \\
\text { Англиски } \\
\text { Англиский } \\
\rightarrow\end{array}$ & $\begin{array}{c}\text { Russian } \\
\text { Руски } \\
\text { Русский язык } \\
\rightarrow\end{array}$ \\
\hline 7. & & еБАаН & $\begin{array}{c}\text { На Врховната бебе } \\
\text { (дете) }\end{array}$ & $\begin{array}{l}\text { Of a Supreme Baby } \\
\text { (child) }\end{array}$ & $\begin{array}{c}\text { Верховний ребенок } \\
\text { (дитя) }\end{array}$ \\
\hline 8. & $>\| 1$ & ооЧоДАаН & На Врховната ќерка & Of a Supreme daughter & Верховной дочь \\
\hline 9. & & HoPA & На Врховната Куќа ни & Of our Supreme House & Наш Верховный дом \\
\hline 10. & & HoMA & А Голема Мајка ни & Our Great Mother & $\begin{array}{c}\text { А наша большая } \\
\text { мать }\end{array}$ \\
\hline 11. & $\geq \leq$ & ${ }_{\mathrm{b}} \mathrm{CeeC} \mathrm{A}$ aH & На Врховна сите се & All belongs to the Supreme & На всех Верховная \\
\hline \multicolumn{6}{|c|}{ Б } \\
\hline 12. & & оБ & Душа & Soul & Дух \\
\hline 13. & & ИоБ & Души & Souls & Духов \\
\hline 14. & & ИоБьЈаН & $\begin{array}{c}\text { Нај(добри) души; } \\
\text { научници (филозофи) }\end{array}$ & $\begin{array}{c}\text { Best souls (Scientists; Phi- } \\
\text { losophers) }\end{array}$ & $\begin{array}{c}\text { Самие (добрие) } \\
\text { духов, научники } \\
\text { (филозофи ) }\end{array}$ \\
\hline 15. & $\mathbf{U}$ & ооБ & Врховна (небесна) душа & Supreme (Heavenly) Soul & Верховая (небесная) \\
\hline 16. & & еЗеВоБ & Душа дава (запишува) & $\begin{array}{l}\text { Gives his soul } \\
\text { (loves someone) }\end{array}$ & $\begin{array}{c}\text { Душа дает } \\
\text { (записивает) }\end{array}$ \\
\hline
\end{tabular}




\begin{tabular}{|c|c|c|c|c|c|}
\hline & $\begin{array}{l}\text { The original } \\
\text { Оригинал } \\
\text { Оригинал }\end{array}$ & $\begin{array}{c}\text { Cyrillic transcription } \\
\text { Кирилична транскрипција } \\
\text { Кириличная транскрипция } \\
\leftarrow\end{array}$ & $\begin{array}{c}\text { Contemporary Macedonian } \\
\text { Современ македонски } \\
\text { Современный македонский } \\
\text { язык } \\
\rightarrow \\
\end{array}$ & $\begin{array}{c}\text { English } \\
\text { Англиски } \\
\text { Англиский } \\
\rightarrow \\
\end{array}$ & $\begin{array}{c}\text { Russian } \\
\text { Руски } \\
\text { Русский язык } \\
\rightarrow \\
\end{array}$ \\
\hline 17. & & оТеВеВ аН врП еЗеВоБ & $\begin{array}{c}\text { Душа дава прв на } \\
\text { државата }\end{array}$ & $\begin{array}{c}\text { Gives his soul first for the } \\
\text { country }\end{array}$ & $\begin{array}{c}\text { Душа дает впервие } \\
\text { для государства }\end{array}$ \\
\hline 18 & & НееЖоБ & Божествен & Divine & Божествений \\
\hline 19. & & НееЖоБьЈаН & $\begin{array}{c}\text { Најбожествен Врховен } \\
\text { (АЛЕКСАНДАР) }\end{array}$ & $\begin{array}{c}\text { Most divine } \\
\text { (ALEXANDER) }\end{array}$ & $\begin{array}{c}\text { Самий божествений } \\
\text { Верховний } \\
\text { (АЛЕКСАНДАР) }\end{array}$ \\
\hline 20. & & еНееЖоБьЈаН & Најбожественине & Those most divine & Самий божествений \\
\hline 21. & $E$ & еБ & Бебе (дете) & Baby (child) & Бебе (ребенок) \\
\hline 22. & $\| n$ & еДьБ & Да биде & To be & Бить \\
\hline 23. & & ооГоБ & $\begin{array}{c}\text { Душа што твори } \\
\text { (Творец) }\end{array}$ & Soul that creates (Creator) & $\begin{array}{c}\text { Душа которая } \\
\text { творить (Творец) }\end{array}$ \\
\hline 24. & & ооГоБ аН ооГоБ & $\begin{array}{c}\text { Бог на Бог } \\
\text { (Двобог; Дионис) }\end{array}$ & $\begin{array}{c}\text { God of God } \\
\text { (Twogod; Dionis) }\end{array}$ & Дионис \\
\hline 25. & & НеВ оВ ооГоБ & $\begin{array}{c}\text { Градба на Богот на } \\
\text { водата (канал за вода) }\end{array}$ & $\begin{array}{c}\text { Construction of the God of } \\
\text { water (Water canal) }\end{array}$ & $\begin{array}{c}\text { Строительство } \\
\text { Бога води } \\
\text { (Водний канал) }\end{array}$ \\
\hline 26. & & Н оТооГоБ & Богот ни & Our God & Бог наш \\
\hline
\end{tabular}




\begin{tabular}{|c|c|c|c|c|c|}
\hline & $\begin{array}{l}\text { The original } \\
\text { Оригинал } \\
\text { Оригинал }\end{array}$ & $\begin{array}{c}\text { Cyrillic transcription } \\
\text { Кирилична транскрипција } \\
\text { Кириличная транскрипция } \\
\leftarrow\end{array}$ & $\begin{array}{c}\text { Contemporary Мacedonian } \\
\text { Современ македонски } \\
\text { Современный македонский } \\
\text { язык } \\
\rightarrow\end{array}$ & $\begin{array}{l}\text { English } \\
\text { Англиски } \\
\text { Англиский } \\
\rightarrow\end{array}$ & $\begin{array}{l}\text { Russian } \\
\text { Руски } \\
\text { Русский язык } \\
\rightarrow\end{array}$ \\
\hline \multicolumn{6}{|c|}{ B } \\
\hline 27. & $<$ & $\mathrm{eB}$ & Мајстор; Градба & $\begin{array}{c}\text { Handicraftsman; Construc- } \\
\text { tion }\end{array}$ & $\begin{array}{c}\text { Мастер; } \\
\text { Строительство }\end{array}$ \\
\hline 28. & & ИеВ & Мајстори; Градби & $\begin{array}{l}\text { Handicraftsmen; } \\
\text { Constructions }\end{array}$ & $\begin{array}{c}\text { Мастера; } \\
\text { Строительства }\end{array}$ \\
\hline 29. & & Н ИеВ & Градби ни & Our construction & Наши строительства \\
\hline 30 & & $\mathrm{eBeB}$ & $\begin{array}{c}\text { Држава } \\
\text { (Мајстор мајстор) } \\
\text { (Градба градба) }\end{array}$ & $\begin{array}{c}\text { State } \\
\text { (Workman Workman) } \\
\text { (Construction Construction) }\end{array}$ & Государство \\
\hline 31. & & H оТеВеВ & Државата ни & Our state & Государство наше \\
\hline 32. & & $\mathrm{eHeB}$ & Роденден; Творење & Birthday; Creation Day & $\begin{array}{c}\text { Деньрождения; } \\
\text { Творить }\end{array}$ \\
\hline 33. & $4<$ & e3eB & Пишува; Везе & Write; Embroider & Писать; Вязать \\
\hline 34 & & НeЗеB & Пишан; Везен & Written; Embroidered & $\begin{array}{l}\text { Написаний; } \\
\text { Навязаний }\end{array}$ \\
\hline 35 & 7 & eḰeB aH & На векови (вечен) & To centuries (Eternal) & $\begin{array}{c}\text { На века (навсегда), } \\
\text { вечний }\end{array}$ \\
\hline
\end{tabular}




\begin{tabular}{|c|c|c|c|c|c|}
\hline & $\begin{array}{l}\text { The original } \\
\text { Оригинал } \\
\text { Оригинал }\end{array}$ & $\begin{array}{c}\text { Cyrillic transcription } \\
\text { Кирилична транскрипција } \\
\text { Кириличная транскрипция } \\
\leftarrow\end{array}$ & $\begin{array}{c}\text { Contemporary Macedonian } \\
\text { Современ македонски } \\
\text { Современный македонский } \\
\text { язык } \\
\rightarrow \\
\end{array}$ & $\begin{array}{l}\text { English } \\
\text { Англиски } \\
\text { Англиский } \\
\rightarrow\end{array}$ & $\begin{array}{c}\text { Russian } \\
\text { Руски } \\
\text { Русский язык } \\
\rightarrow\end{array}$ \\
\hline 36. & & НьВоКеВ & Вековен & For centuries & На веки (вачний) \\
\hline 37. & & $\mathrm{HeBaH}$ & Направен & Created & Сделан \\
\hline 38. & & BB & Bo & In & B \\
\hline 39. & $\boldsymbol{V}$ & ooB & $\begin{array}{l}\text { Сонце; Водач; } \\
\text { Небесна вода }\end{array}$ & $\begin{array}{l}\text { Sun; Supreme leader; } \\
\text { Heavenly water }\end{array}$ & $\begin{array}{l}\text { Солнце; Вождь; } \\
\text { Вождь небесний }\end{array}$ \\
\hline 40. & & отоoB & Сонцето; Водачот & $\begin{array}{c}\text { The Sun; The Supreme } \\
\text { leader }\end{array}$ & Солнце; Вождь \\
\hline 41. & 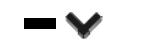 & AooB & Оваа & This & Эта \\
\hline 42. & & ИооВ & Овие & These & Эти \\
\hline 43. & $\boldsymbol{J}$ & ooJooB & Овој; оваа & This & Этот, эта \\
\hline 44. & $\rightarrow V$ & ьЈоoB & Овој & This & Этот \\
\hline 45. & 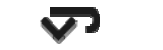 & oоJooBaH & На оваа & To this & На эта \\
\hline 46. & & ьуЃ ооЈооBаH & $\begin{array}{l}\text { На оваа убава земја; } \\
\text { На овој Египет }\end{array}$ & $\begin{array}{l}\text { Of this Beautiful land; } \\
\text { Of this Egypt }\end{array}$ & $\begin{array}{c}\text { На этой красивои } \\
\text { земле; На этом } \\
\text { Египете }\end{array}$ \\
\hline 47. & 人 & ьВ & Врвен (Врховник) & Greatest (Supreme) & Самий виший \\
\hline
\end{tabular}




\begin{tabular}{|c|c|c|c|c|c|}
\hline & $\begin{array}{l}\text { The original } \\
\text { Оригинал } \\
\text { Оригинал }\end{array}$ & $\begin{array}{c}\text { Cyrillic transcription } \\
\text { Кирилична транскрипција } \\
\text { Кириличная транскрипция } \\
\leftarrow\end{array}$ & $\begin{array}{c}\text { Contemporary Macedonian } \\
\text { Современ македонски } \\
\text { Современный македонский } \\
\text { язык } \\
\rightarrow \\
\end{array}$ & $\begin{array}{c}\text { English } \\
\text { Англиски } \\
\text { Англиский } \\
\rightarrow \\
\end{array}$ & $\begin{array}{c}\text { Russian } \\
\text { Руски } \\
\text { Русский язык } \\
\rightarrow \\
\end{array}$ \\
\hline 48. & 入 & ооЈьВаН & Најврвниот & Most supreme & Вишейший, \\
\hline \multicolumn{6}{|c|}{$\Gamma$} \\
\hline 49. & $\perp$ & ооГ & Творец & Creator & Создатель \\
\hline 50. & -1 & $\mathrm{o} \Gamma$ & Него & Him & Его \\
\hline 51. & & еeЦоГаН & Негов ценет & His esteemed & Его почтенниий \\
\hline 52. & HI & адопсоГ & Господа & Lord & Господь \\
\hline 53. & y & радопсоГ & Господар & Master & Государь \\
\hline 54. & IAl & ИрадопсоГ & Господари & Masters & Государьи \\
\hline 55. & (Alp & оТрадопсоГ & Господарот & The Master & Государь \\
\hline 56. & 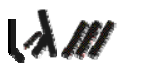 & аТрадопсоГ & Господарите & The Masters & Государьем \\
\hline \multicolumn{6}{|c|}{ Д } \\
\hline 57. & ل & ед & Божество & Deity & Божество \\
\hline 58. & $\cap \|$ & ООеД & $\begin{array}{c}\text { Божество Врховно } \\
\text { на небото }\end{array}$ & Supreme Deity on heaven & $\begin{array}{c}\text { Верховное божество } \\
\text { на небесах }\end{array}$ \\
\hline
\end{tabular}




\begin{tabular}{|c|c|c|c|c|c|}
\hline & $\begin{array}{l}\text { The original } \\
\text { Оригинал } \\
\text { Оригинал }\end{array}$ & $\begin{array}{c}\text { Cyrillic transcription } \\
\text { Кирилична транскрипција } \\
\text { Кириличная транскрипция } \\
\leftarrow\end{array}$ & $\begin{array}{c}\text { Contemporary Масеdonian } \\
\text { Современ македонски } \\
\text { Современный македонский } \\
\text { язык } \\
\rightarrow\end{array}$ & $\begin{array}{l}\text { English } \\
\text { Англиски } \\
\text { Англиский } \\
\rightarrow\end{array}$ & $\begin{array}{c}\text { Russian } \\
\text { Руски } \\
\text { Русский язык } \\
\rightarrow\end{array}$ \\
\hline 59. & $\mathbf{u}$ & ьед & $\begin{array}{c}\text { Божество Врховно } \\
\text { на земјата }\end{array}$ & Supreme Deity on Earth & $\begin{array}{c}\text { Верховное божество } \\
\text { на земле }\end{array}$ \\
\hline 60. & & Аед & Божица Врховна & Supreme Goddess & Верховная богиня \\
\hline 61. & & АеДаН & На Божица Врховна & Of the Supreme Goddess & Верхожной богине \\
\hline 62. & & оТоПАеДаН & $\begin{array}{c}\text { На Божица Врховна } \\
\text { градот (Теба) }\end{array}$ & $\begin{array}{c}\text { The City of the Supreme } \\
\text { Goddess (Theba) }\end{array}$ & $\begin{array}{c}\text { Город Верховной } \\
\text { богине (Теба) }\end{array}$ \\
\hline 63. & & Н ед & Божество ни & Our Deity & Божество наше \\
\hline 64. & & ееЖед & $\begin{array}{c}\text { Божество на земјина } \\
\text { енергија } \\
\text { (Божество на Живот) }\end{array}$ & $\begin{array}{l}\text { Deity of Earth's energy } \\
\text { (Deity of Life) }\end{array}$ & $\begin{array}{l}\text { Божество енергии } \\
\text { земной } \\
\text { (Божевство жизни) }\end{array}$ \\
\hline 65. & & иТеДаН & На Божествата ни & Of our Deities & Для нашего Божества \\
\hline 66. & & аЦед & $\mid \begin{array}{c}\text { Деца } \\
\text { (Отелотворени божества) }\end{array}$ & $\begin{array}{c}\text { Children } \\
\text { (Embodied Deities) }\end{array}$ & $\begin{array}{c}\text { Дети (Отелотворение } \\
\text { божества) }\end{array}$ \\
\hline 67. & 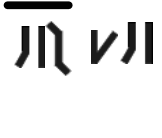 & АедоМ аН аЦед & $\begin{array}{c}\text { Деца на Голема Мајка } \\
\text { Божица Врховна } \\
\text { (Македонци) }\end{array}$ & $\begin{array}{l}\text { Children of Great Mother } \\
\text { Supreme Goddess } \\
\text { (Macedonians) }\end{array}$ & $\begin{array}{c}\text { Дети Больщои матери } \\
\text { Богини Верховной } \\
\text { (Македонци) }\end{array}$ \\
\hline
\end{tabular}




\begin{tabular}{|c|c|c|c|c|c|}
\hline & $\begin{array}{c}\text { The original } \\
\text { Оригинал } \\
\text { Оригинал }\end{array}$ & $\begin{array}{c}\text { Cyrillic transcription } \\
\text { Кирилична транскрипција } \\
\text { Кириличная транскрипция } \\
\leftarrow\end{array}$ & $\begin{array}{c}\text { Contemporary Macedonian } \\
\text { Современ македонски } \\
\text { Современный македонский } \\
\text { язык } \\
\rightarrow \\
\end{array}$ & $\begin{array}{c}\text { English } \\
\text { Англиски } \\
\text { Англиский } \\
\rightarrow \\
\end{array}$ & $\begin{array}{c}\text { Russian } \\
\text { Руски } \\
\text { Русский язык } \\
\rightarrow \\
\end{array}$ \\
\hline 68. & $|v|$ & ом аЦед & $\begin{array}{c}\text { Деца Мајчини } \\
\text { (Македонци) }\end{array}$ & $\begin{array}{l}\text { Children of Great Mother } \\
\text { (Macedonians) }\end{array}$ & $\begin{array}{c}\text { Дети Большои матери } \\
\text { (Македонци) }\end{array}$ \\
\hline 69. & $\checkmark$ & ооВ аЦед & $\begin{array}{l}\text { Деца Сончеви } \\
\text { (Македонци) }\end{array}$ & $\begin{array}{l}\text { Children of the Sun } \\
\text { (Macedonians) }\end{array}$ & $\begin{array}{l}\text { Дети Солнца } \\
\text { (Македонци) }\end{array}$ \\
\hline 70. & & ьуЃ ооЈооВ аН аЦед & $\begin{array}{c}\text { Деца на оваа Убава Земја } \\
\text { (Египет на древномаке- } \\
\text { донски) Египќани }\end{array}$ & $\begin{array}{l}\text { Children of this Beautiful } \\
\text { Land (Egypt on Ancient } \\
\text { Macedonian language) }\end{array}$ & $\begin{array}{c}\text { Дети этой Красивой } \\
\text { Земли (Египет, } \\
\text { древних македонцев) } \\
\text { Египтяни }\end{array}$ \\
\hline 71. & & $\begin{array}{c}\text { аЦед } \\
\text { аврП (А) ајим3 аН }\end{array}$ & $\begin{array}{l}\text { Деца на Змија Врховна } \\
\quad \text { (Данајци = Грци) }\end{array}$ & $\begin{array}{l}\text { Children of the Supreme } \\
\text { Snake (Danaans (Greeks) }\end{array}$ & $\begin{array}{c}\text { Дети Змей Верховной } \\
(\text { Данайци }=\text { Греки })\end{array}$ \\
\hline 72. & 3 & еВоМьЈ аЦед & $\begin{array}{c}\text { Деца на (Голема) Мајка } \\
\text { неприродна (Волчица) } \\
\text { (Жители на Градот на } \\
\text { волците) (Римјани) }\end{array}$ & $\begin{array}{l}\text { Children of (Great) Mother } \\
\text { unnatural (She-wolf) } \\
\text { (Citizens of the Wolf } \\
\text { City - Lycopolis) }\end{array}$ & $\begin{array}{c}\text { Дети (Болжшой) } \\
\text { Матери неприрод- } \\
\text { ной/искуственой } \\
\text { (Волчице) (Жители } \\
\text { города Волков) } \\
\text { (Римляни) }\end{array}$ \\
\hline 73. & 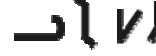 & ьЈоМ аЦед & Деца мои & My children & Дети мои \\
\hline
\end{tabular}




\begin{tabular}{|c|c|c|c|c|c|}
\hline & $\begin{array}{l}\text { The original } \\
\text { Оригинал } \\
\text { Оригинал }\end{array}$ & $\begin{array}{c}\text { Cyrillic transcription } \\
\text { Кирилична транскрипција } \\
\text { Кириличная транскрипция } \\
\leftarrow\end{array}$ & $\begin{array}{c}\text { Contemporary Macedonian } \\
\text { Современ македонски } \\
\text { Современный македонский } \\
\text { язык } \\
\rightarrow\end{array}$ & $\begin{array}{c}\text { English } \\
\text { Англиски } \\
\text { Англиский } \\
\rightarrow\end{array}$ & $\begin{array}{c}\text { Russian } \\
\text { Руски } \\
\text { Русский язык } \\
\rightarrow\end{array}$ \\
\hline 74. & $V$ & $\begin{array}{c}\text { ьЈаН } \\
\text { аЦНеМИ(врП)еeS aH } \\
\text { аЦед }\end{array}$ & $\begin{array}{c}\text { На Најсветлото Име деца } \\
\text { (Фараонови деца) } \\
\text { (поданици) }\end{array}$ & $\begin{array}{c}\text { Pharaoh's children } \\
\text { (Subjects) }\end{array}$ & $\begin{array}{c}\text { Дети Фараона } \\
\text { (подданики) }\end{array}$ \\
\hline 75. & & иТеДаН аЦед & $\begin{array}{c}\text { Деца на божества ни } \\
\text { (Оние што влегуваат во } \\
\text { погребната просторија) }\end{array}$ & $\begin{array}{c}\text { Children of our Deities } \\
\text { (Those who can enter in a } \\
\text { chamber) }\end{array}$ & $\begin{array}{c}\text { Дети божества наше- } \\
\text { го (те кто входят в } \\
\text { усыпальниц) }\end{array}$ \\
\hline 76. & & оМеШ ом аЦед & $\begin{array}{c}\text { На Деца Мајчини свеш- } \\
\text { теник (Пророк) }\end{array}$ & $\begin{array}{l}\text { Priest of the Children of } \\
\text { the Great Mother (Prophet) }\end{array}$ & $\begin{array}{c}\text { Дети священиков } \\
\text { (Пророк) }\end{array}$ \\
\hline 77. & & eeS оМооГоБ аЦед & $\begin{array}{c}\text { Мајчини деца на } \\
\text { Божицата Сончевата } \\
\text { светлина, Врховни } \\
\text { свештеници - Архијереи }\end{array}$ & $\begin{array}{l}\text { Children of Goddess, be- } \\
\text { longing to Gods of the } \\
\text { Great Mother, of Sun Light } \\
\text { (High priests; Archpriests) }\end{array}$ & $\begin{array}{c}\text { Дети Богине, } \\
\text { Большой матери, } \\
\text { Солнечного света, } \\
\text { Верховние свяще- } \\
\text { ники - Архиереи }\end{array}$ \\
\hline 78. & & ооХ ооГоБ аН аЦед & $\begin{array}{c}\text { Деца на Божицата на } \\
\text { писменоста (Научници; } \\
\text { Писари) }\end{array}$ & $\begin{array}{c}\text { Children of the Goddess } \\
\text { of Literacy (Scholars; } \\
\text { Clerks) }\end{array}$ & $\begin{array}{c}\text { Дети Богини } \\
\text { граммотности } \\
\text { Научники; Писари } \\
\text { (книжники) }\end{array}$ \\
\hline 79. & 1 & оМад & Да дадеме & To give & Дать \\
\hline
\end{tabular}




\begin{tabular}{|c|c|c|c|c|c|}
\hline & $\begin{array}{l}\text { The original } \\
\text { Оригинал } \\
\text { Оригинал }\end{array}$ & $\begin{array}{c}\text { Cyrillic transcription } \\
\text { Кирилична транскрипција } \\
\text { Кириличная транскрипция } \\
\leftarrow\end{array}$ & $\begin{array}{c}\text { Contemporary Масеdonian } \\
\text { Современ македонски } \\
\text { Современный македонский } \\
\text { язык } \\
\rightarrow\end{array}$ & $\begin{array}{l}\text { English } \\
\text { Англиски } \\
\text { Англиский } \\
\rightarrow\end{array}$ & $\begin{array}{c}\text { Russian } \\
\text { Руски } \\
\text { Русский язык } \\
\rightarrow\end{array}$ \\
\hline 80. & & оМаД ооВ & $\begin{array}{c}\text { На водачот (небесен) } \\
\text { да дадеме } \\
\text { (данок) }\end{array}$ & $\begin{array}{l}\text { To give to the supreme } \\
\text { (heavenly) leader } \\
\text { (tax) }\end{array}$ & $\begin{array}{c}\text { Лидеру небесному } \\
\text { дать } \\
\text { (налог) }\end{array}$ \\
\hline 81. & & еВьЈаНед & $\begin{array}{c}\text { Данајци (означува Грци } \\
\text { на древномакедонски } \\
\text { јазик) }\end{array}$ & $\begin{array}{l}\text { Danaans (Greeks on An- } \\
\text { cient Macedonian lan- } \\
\text { guage) }\end{array}$ & $\begin{array}{l}\text { Данайци (означает } \\
\text { „Греки” на древне- } \\
\text { македонском языке) }\end{array}$ \\
\hline 82. & & ооЧод & Ќерка & Daughter & Дочь \\
\hline 83. & & уЈ ооЧод & Ќерка нејзина & Daughter of her & Ее дочь \\
\hline 84. & & еВид & Восхитува; диви & Admire & $\begin{array}{c}\text { Восхищатся; } \\
\text { удивляется }\end{array}$ \\
\hline 85. & & оЈеВид & Се восхитува; се диви & To admire & $\begin{array}{c}\text { Восхощается; } \\
\text { удивляется }\end{array}$ \\
\hline 86. & 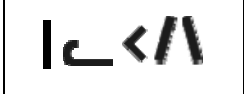 & ИееЈеВиД & Се восхитуваат; се диват & They admire & $\begin{array}{c}\text { Восхищаются; } \\
\text { удивляются }\end{array}$ \\
\hline 87. & $\mid \subset<$ IIIII $\mid$ & $\begin{array}{c}\text { оМооГоБ ьЈоТ } \\
\text { ИееЈеВид }\end{array}$ & $\begin{array}{c}\text { Нему Боговите } \\
\text { на Големата Мајка } \\
\text { му се восхитуваат }\end{array}$ & $\begin{array}{l}\text { The Gods of the Great } \\
\text { Mother admired him } \\
\text { (Epiphen) }\end{array}$ & $\begin{array}{c}\text { Ему Боги Великой } \\
\text { Матери восхищаются } \\
\text { (Epiphan) }\end{array}$ \\
\hline
\end{tabular}




\begin{tabular}{|c|c|c|c|c|c|}
\hline & $\begin{array}{l}\text { The original } \\
\text { Оригинал } \\
\text { Оригинал }\end{array}$ & $\begin{array}{c}\text { Cyrillic transcription } \\
\text { Кирилична транскрипција } \\
\text { Кириличная транскрипция } \\
\leftarrow\end{array}$ & $\begin{array}{c}\text { Contemporary Macedonian } \\
\text { Современ македонски } \\
\text { Современный македонский } \\
\text { язык } \\
\rightarrow \\
\end{array}$ & $\begin{array}{c}\text { English } \\
\text { Англиски } \\
\text { Англиский } \\
\rightarrow\end{array}$ & $\begin{array}{c}\text { Russian } \\
\text { Руски } \\
\text { Русский язык } \\
\rightarrow\end{array}$ \\
\hline 88. & $|c<I|$ ||| & $\begin{array}{c}\text { оМооГоБ ееЗьЈаН } \\
\text { ИееЈеВид }\end{array}$ & $\begin{array}{c}\text { Нејзе Боговите на } \\
\text { Големата Мајка и се } \\
\text { восхитуваат }\end{array}$ & $\begin{array}{l}\text { The Gods of the Great } \\
\text { Mother admired her } \\
\text { (Epiphania) }\end{array}$ & $\begin{array}{c}\text { Ею Боги Великой } \\
\text { Матери восхищаются } \\
\text { (Epiphania) }\end{array}$ \\
\hline 89. & $c<\gamma \|$ & еeJ C еH ед & $\begin{array}{c}\text { Божество Врховник } \\
\text { на сѐ е }\end{array}$ & $\begin{array}{l}\text { Everything belongs } \\
\text { to the Supreme Deity }\end{array}$ & $\begin{array}{c}\text { Божество верховное } \\
\text { всего }\end{array}$ \\
\hline \multicolumn{6}{|c|}{$\dot{\Gamma}$} \\
\hline 90. & & $\mathrm{e} \Gamma$ & Човек & Man & Человек \\
\hline 91. & & еѓoM & $\begin{array}{c}\text { Човек од Голема Мајка } \\
\text { (Македонец) }\end{array}$ & $\begin{array}{l}\text { Man of Great Mother } \\
\text { (Macedonian) }\end{array}$ & $\begin{array}{c}\text { Человек Большой } \\
\text { Матери (Македонец) }\end{array}$ \\
\hline 92. & & егу уЛ & $\begin{array}{l}\text { Човек од Египет } \\
\text { (Египќани) }\end{array}$ & Man of Egypt (Egyptian) & Человек Египта \\
\hline 93. & & еѓу & $\begin{array}{c}\text { Човек } \\
\text { од градот на волците }\end{array}$ & $\begin{array}{l}\text { Man from the Wolf City } \\
\text { (Lycopolis) }\end{array}$ & $\begin{array}{c}\text { Человек волчьего } \\
\text { города }\end{array}$ \\
\hline 94. & | & y & $\begin{array}{c}\text { Убавка (Голема Мајка } \\
\text { на Египет) }\end{array}$ & $\begin{array}{c}\text { Beauty (The Great Mother } \\
\text { of Egypt) }\end{array}$ & $\begin{array}{c}\text { Красивая (Больщая } \\
\text { мать Египта) }\end{array}$ \\
\hline 95. & $\cup J$ & ьуЃ & $\begin{array}{l}\text { Убава земја } \\
\text { (Египет) }\end{array}$ & $\begin{array}{c}\text { Beautiful land } \\
\text { (Egypt on Ancient } \\
\text { Macedonian language) }\end{array}$ & $\begin{array}{c}\text { Красивая земля } \\
\text { (Египет) }\end{array}$ \\
\hline
\end{tabular}




\begin{tabular}{|c|c|c|c|c|c|}
\hline & $\begin{array}{l}\text { The original } \\
\text { Оригинал } \\
\text { Оригинал }\end{array}$ & $\begin{array}{c}\text { Cyrillic transcription } \\
\text { Кирилична транскрипција } \\
\text { Кириличная транскрипция } \\
\leftarrow\end{array}$ & $\begin{array}{c}\text { Contemporary Macedonian } \\
\text { Современ македонски } \\
\text { Современный македонский } \\
\text { язык } \\
\rightarrow\end{array}$ & $\begin{array}{l}\text { English } \\
\text { Англиски } \\
\text { Англиский } \\
\rightarrow\end{array}$ & $\begin{array}{c}\text { Russian } \\
\text { Руски } \\
\text { Русский язык } \\
\rightarrow\end{array}$ \\
\hline 96. & $V$ & аЦаПьуѓ & $\begin{array}{l}\text { Жители на Египет } \\
\text { (Египќани) }\end{array}$ & $\begin{array}{c}\text { Citizens of Egypt (Egyp- } \\
\text { tians) }\end{array}$ & $\begin{array}{l}\text { Житель Египта } \\
\text { (Египтяни) }\end{array}$ \\
\hline 97. & & аЦаПьуѓ & $\begin{array}{c}\text { Жителиве на Египет } \\
\text { (Египќани) }\end{array}$ & $\begin{array}{l}\text { These citizens of Egypt } \\
\text { (Egyptians) }\end{array}$ & $\begin{array}{l}\text { Жители Египта } \\
\text { (Египтяни) }\end{array}$ \\
\hline 98. & & оТоП А ьуЃ аН & $\begin{array}{l}\text { На Египет А (Главен) } \\
\text { (градот Александрија) }\end{array}$ & $\begin{array}{l}\text { Of Egypt first } \\
\text { (main) city } \\
\text { (Alexandria) }\end{array}$ & $\begin{array}{c}\text { Первий город А } \\
\text { (Главний/столица) } \\
\text { город Египта } \\
\text { (Александрия) }\end{array}$ \\
\hline 99. & & Н y $\Gamma ́$ & Нил (Убав ни) & Nile & Нил (красивая наша) \\
\hline 100. & & $\mathrm{H}$ yЃ aH & На Нил (На Убав ни) & On Nile & $\begin{array}{c}\text { На Ниле (на красивой } \\
\text { нашей) }\end{array}$ \\
\hline 101. & 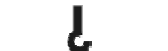 & $\mathrm{a} \Gamma$ & Војна & War & Война \\
\hline 102. & & еНаПьЃ аН & $\begin{array}{c}\text { На Египќани од Горен } \\
\text { Египет }\end{array}$ & $\begin{array}{l}\text { Of Egyptians from Upper } \\
\text { Egypt }\end{array}$ & $\begin{array}{c}\text { Египтянам, Горного } \\
\text { Египта }\end{array}$ \\
\hline 103. & & еВьЈаНед оМаПьЃ аН & $\begin{array}{c}\text { На Горно-египетски } \\
\text { Данајци }\end{array}$ & $\begin{array}{c}\text { Of Danaans from Upper } \\
\text { Egypt }\end{array}$ & $\begin{array}{l}\text { Данейцом, горного } \\
\text { Египта }\end{array}$ \\
\hline \multicolumn{6}{|c|}{$\mathbf{E}$} \\
\hline
\end{tabular}




\begin{tabular}{|c|c|c|c|c|c|}
\hline & $\begin{array}{l}\text { The original } \\
\text { Оригинал } \\
\text { Оригинал }\end{array}$ & $\begin{array}{c}\text { Cyrillic transcription } \\
\text { Кирилична транскрипција } \\
\text { Кириличная транскрипция } \\
\leftarrow\end{array}$ & $\begin{array}{c}\text { Contemporary Macedonian } \\
\text { Современ македонски } \\
\text { Современный македонский } \\
\text { язык } \\
\rightarrow \\
\end{array}$ & $\begin{array}{c}\text { English } \\
\text { Англиски } \\
\text { Англиский } \\
\rightarrow \\
\end{array}$ & $\begin{array}{c}\text { Russian } \\
\text { Руски } \\
\text { Русский язык } \\
\rightarrow \\
\end{array}$ \\
\hline \multicolumn{6}{|c|}{ Ж } \\
\hline 104. & 2 & ееЖ & Животна енергија & Life energy & Жизненая энергия \\
\hline 105. & & еВееЖ & Живо & Live & Живое \\
\hline 106. & & уНеВееЖ & Живион & Alive & Живой \\
\hline 107. & & уНеВееЖ ьЈаН & Најживион (Вечниот) & Most living (Eternal) & Вечний \\
\hline 108. & & еВИееЖ & Жививе & These lives & Жить \\
\hline 109. & & оТеВееЖ & Живото & The alive & Живое \\
\hline 110. & & еВуЈееЖ & Нивни живи & Their lives & Их живих \\
\hline 111. & & ИаП уљееЖ & Добродетел & Benefactor & Добродетель \\
\hline 112. & & оТИаП уљееЖ & Добродетелот & The benefactor & Добродетель \\
\hline 113. & & оЖ & Заштитник & Protector & Защитник \\
\hline 114. & $\mathbf{U}$ & оЖ врП & Прв заштитник & First protector & Первий защитник \\
\hline 115. & & НаП оЖ & \begin{tabular}{|c|} 
Заштитник врховен ни \\
$($ Жупан - Градоначалник)
\end{tabular} & $\begin{array}{c}\text { Our supreme protector } \\
\text { (Mayor) }\end{array}$ & $\begin{array}{c}\text { Защитник наш } \\
\text { верховний (Мэр) }\end{array}$ \\
\hline
\end{tabular}




\begin{tabular}{|c|c|c|c|c|c|}
\hline & $\begin{array}{l}\text { The original } \\
\text { Оригинал } \\
\text { Оригинал }\end{array}$ & $\begin{array}{c}\text { Cyrillic transcription } \\
\text { Кирилична транскрипција } \\
\text { Кириличная транскрипция } \\
\leftarrow\end{array}$ & $\begin{array}{c}\text { Contemporary Macedonian } \\
\text { Современ македонски } \\
\text { Современный македонский } \\
\text { язык } \\
\rightarrow\end{array}$ & $\begin{array}{l}\text { English } \\
\text { Англиски } \\
\text { Англиский } \\
\rightarrow\end{array}$ & $\begin{array}{c}\text { Russian } \\
\text { Руски } \\
\text { Русский язык } \\
\rightarrow\end{array}$ \\
\hline \multicolumn{6}{|c|}{3} \\
\hline 116. & & e3 & $\begin{array}{l}\text { Младо сонце } \\
\text { (Пта; Хорус) }\end{array}$ & Young sun (Ptah; Horus) & $\begin{array}{c}\text { Молодое солнце } \\
\text { (Пта, Хорус) }\end{array}$ \\
\hline 117. & & oTe3 & $\begin{array}{c}\text { Младото сонце } \\
\text { (Младоженец; Зет) }\end{array}$ & The young sun (the broom) & (Это) молодое солнце \\
\hline 118. & 2 & ee3 & $\begin{array}{c}\text { Месечева } \\
\text { (ладна) светлина }\end{array}$ & Moon (cold) light & $\begin{array}{c}\text { Лунний (холодний) } \\
\text { свет }\end{array}$ \\
\hline 119. & 2 & еeЗьЈаH & Најсветла - Нејзе & To her & Ей \\
\hline 120. & & оЈаНееСИаНееЗьЈаН & $\begin{array}{c}\text { Најзаносна; Убавица на } \\
\text { татковината (Клеопатра) }\end{array}$ & $\begin{array}{l}\text { Most beautiful (Beauty) } \\
\text { of the country (Cleopatra) }\end{array}$ & $\begin{array}{c}\text { Самая очарователь- } \\
\text { ная; Красавица } \\
\text { родини (Клеопатра) }\end{array}$ \\
\hline 121. & 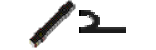 & Hee3 & Ладна светлина ни & Our moon (cold) light & Холодний свет наш \\
\hline 122. & 2 & Hee3aH & На ладна светлина ни & Of our moon (cold) light & $\begin{array}{c}\text { На холодном свете } \\
\text { нашем }\end{array}$ \\
\hline 123. & 2 & Aee3aH & Нарица; Призива & Pray; Appeal & Призвать \\
\hline 124. & 2 & oMAeeЗаH & Нарекуваме & We call; We name & Називаем \\
\hline
\end{tabular}




\begin{tabular}{|c|c|c|c|c|c|}
\hline & $\begin{array}{l}\text { The original } \\
\text { Оригинал } \\
\text { Оригинал }\end{array}$ & $\begin{array}{c}\text { Cyrillic transcription } \\
\text { Кирилична транскрипција } \\
\text { Кириличная транскрипция } \\
\leftarrow\end{array}$ & $\begin{array}{c}\text { Contemporary Macedonian } \\
\text { Современ македонски } \\
\text { Современный македонский } \\
\text { язык } \\
\rightarrow\end{array}$ & $\begin{array}{c}\text { English } \\
\text { Англиски } \\
\text { Англиский } \\
\rightarrow\end{array}$ & $\begin{array}{c}\text { Russian } \\
\text { Руски } \\
\text { Русский язык } \\
\rightarrow\end{array}$ \\
\hline 125. & & eBee3aH & Нарекува & Call; Name & Називать \\
\hline 126. & & oTeBee3aH & Нарекуваниот & The called; The named & Названний \\
\hline 127. & & HeBee3aH & Нарекуван; Наречен & Called; Named & Називаемий; Назван \\
\hline 128. & & оБеeЗаН & $\begin{array}{c}\text { На свет дух } \\
\text { (На младо сонце душа) }\end{array}$ & Soul of the young sun & $\begin{array}{c}\text { Душа молодого } \\
\text { солнца }\end{array}$ \\
\hline 129. & & ИоТоЛаП оБееЗаН & $\begin{array}{c}\text { Палатите на светиот дух } \\
\text { (душа на младо сонце) } \\
\text { (Пта) (Мемфис) }\end{array}$ & $\begin{array}{c}\text { Palaces of the soul of the } \\
\text { young sun (Ptah) (Mem- } \\
\text { phis) }\end{array}$ & $\begin{array}{c}\text { Палаты духа модого } \\
\text { солнца }\end{array}$ \\
\hline 130. & & аЦНоБееЗаН & $\begin{array}{c}\text { На душа на младо сонце } \\
\text { (Пта) ни жители } \\
\text { (Жители на Мемфис) }\end{array}$ & $\begin{array}{l}\text { Citizens of (the) soul } \\
\text { of young sun (Ptah) } \\
\text { (Citizens of Memphis) }\end{array}$ & $\begin{array}{c}\text { Тем чий защитник } \\
\text { является дух модого } \\
\text { солнца (жители } \\
\text { Мемфиса) }\end{array}$ \\
\hline 131. & & уњоГооВеeЗаН & Неа ја нарекуваат & They call her & Ее називем \\
\hline 132. & 2 & oMee3 & Зима & Winter & Зима \\
\hline 133. & 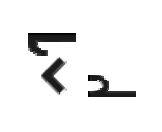 & иШеВаН еe3 & $\begin{array}{c}\text { Ладна светлина на } \\
\text { мајстор на камен } \\
\text { (каменорезец) }\end{array}$ & $\begin{array}{l}\text { Cold light of workman of } \\
\text { stone (stonecutter) }\end{array}$ & $\begin{array}{l}\text { Холодный свет } \\
\text { мастера камня }\end{array}$ \\
\hline
\end{tabular}




\begin{tabular}{|c|c|c|c|c|c|}
\hline & $\begin{array}{l}\text { The original } \\
\text { Оригинал } \\
\text { Оригинал }\end{array}$ & $\begin{array}{c}\text { Cyrillic transcription } \\
\text { Кирилична транскрипција } \\
\text { Кириличная транскрипция } \\
\leftarrow\end{array}$ & $\begin{array}{c}\text { Contemporary Macedonian } \\
\text { Современ македонски } \\
\text { Современный македонский } \\
\text { язык } \\
\rightarrow \\
\end{array}$ & $\begin{array}{c}\text { English } \\
\text { Англиски } \\
\text { Англиский } \\
\rightarrow \\
\end{array}$ & $\begin{array}{c}\text { Russian } \\
\text { Руски } \\
\text { Русский язык } \\
\rightarrow \\
\end{array}$ \\
\hline 134. & & Л еe3 & $\begin{array}{l}\text { Уште и; Ше ле } \\
\text { (словенечки) }\end{array}$ & As well as; And & Еще и .. \\
\hline 135. & & eH Hee3 aH & $\begin{array}{c}\text { На ладна светлина ни } \\
\text { Врховен }\end{array}$ & Supreme of moon light & $\begin{array}{c}\text { Верховный } \\
\text { холодного света }\end{array}$ \\
\hline \multicolumn{6}{|c|}{$\mathbf{S}$} \\
\hline 136. & & $\mathrm{eS}$ & $\begin{array}{l}\text { Оној што гледа сѐ; } \\
\text { Владетел; Пророк }\end{array}$ & $\begin{array}{l}\text { One who sees everything; } \\
\text { Lord; Prophet }\end{array}$ & $\begin{array}{c}\text { Тот которий видит } \\
\text { все; Владетель; } \\
\text { Пророк }\end{array}$ \\
\hline 137. & & oTeS & $\begin{array}{c}\text { Владетелот; Злато; } \\
\text { Пророкот }\end{array}$ & $\begin{array}{l}\text { The One who sees every- } \\
\text { thing; The Lord; Gold; The } \\
\text { prophet }\end{array}$ & $\begin{array}{c}\text { Владетел; Золото; } \\
\text { Пророк }\end{array}$ \\
\hline 138. & & врП(И)eS & Пророк прв & Prophet first & Пророк первий \\
\hline 139. & & аврП(А)eS & Пророчица прва & She-prophet first & Пророчица первая \\
\hline 140. & & ooBeS & $\begin{array}{c}\text { Владетел (Водач; } \\
\text { Господар) на сонцето }\end{array}$ & $\begin{array}{c}\text { The Lord (Leader; Master) } \\
\text { of the Sun }\end{array}$ & $\begin{array}{c}\text { Владетель (Вождь, } \\
\text { Государь) солнца }\end{array}$ \\
\hline 141. & A & $\mathrm{eBeS}$ & Крун & He-crown & Он круна \\
\hline 142. & & $\mathrm{AeBeS}$ & Круна & Crown & Круна \\
\hline
\end{tabular}




\begin{tabular}{|c|c|c|c|c|c|}
\hline & $\begin{array}{l}\text { The original } \\
\text { Оригинал } \\
\text { Оригинал }\end{array}$ & $\begin{array}{c}\text { Cyrillic transcription } \\
\text { Кирилична транскрипција } \\
\text { Кириличная транскрипция } \\
\leftarrow\end{array}$ & $\begin{array}{c}\text { Contemporary Масеdonian } \\
\text { Современ македонски } \\
\text { Современный македонский } \\
\text { язык } \\
\rightarrow\end{array}$ & $\begin{array}{l}\text { English } \\
\text { Англиски } \\
\text { Англиский } \\
\rightarrow\end{array}$ & $\begin{array}{c}\text { Russian } \\
\text { Руски } \\
\text { Русский язык } \\
\rightarrow\end{array}$ \\
\hline 143. & & $\mathrm{AeBeS}$ aH & На круна & Of crown & На круне \\
\hline 144. & & ee3eS & $\begin{array}{c}\text { Владетел (водач; } \\
\text { господар) на ладна } \\
\text { (месечева) светлина } \\
\text { (Тот - египетски бог) }\end{array}$ & $\begin{array}{l}\text { Lord (Leader; Master) of } \\
\text { moon (cold) light (Thoth - } \\
\text { Egyptian God) }\end{array}$ & $\begin{array}{c}\text { Владетвль (лидер; } \\
\text { государь) холодного } \\
\text { (лунного) света (Тот - } \\
\text { египетский бог) }\end{array}$ \\
\hline 145. & 2 & ee3eS ee3eS & Тот Тот (2 пати Тот) & $\begin{array}{l}\text { Thoth Thoth } \\
\text { (2 times Thoth) }\end{array}$ & $\begin{array}{c}\text { Тот Тот } \\
\text { (2 раза Тот) }\end{array}$ \\
\hline 146. & & еТееШееЖаН eS & $\begin{array}{c}\text { Владетелот (Водачот; } \\
\text { Господар) на жештината } \\
(\text { Хефест - Данајски бог) }\end{array}$ & $\begin{array}{c}\text { The Lord (Leader; Master) } \\
\text { of hotness (Hefest - } \\
\text { Danaans (Greek) God) }\end{array}$ & $\begin{array}{c}\text { Владетель (лидер; } \\
\text { государь) жары } \\
\text { (Хефест - Данайский } \\
\text { бог) }\end{array}$ \\
\hline 147. & 5 & eeS & $\begin{array}{c}\text { Сончева светлина } \\
\text { (пладневна жега; ,jара“) }\end{array}$ & Sun light (at noon; heat) & $\begin{array}{l}\text { Солнечний свет } \\
\text { (полдень, ярый) }\end{array}$ \\
\hline 148. & 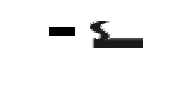 & A(аврП)еeS & $\begin{array}{c}\text { Сончева светлина прва - } \\
\text { ЗОРА }\end{array}$ & $\begin{array}{l}\text { Sun light first - DAWN; } \\
\text { (ISIS - Greek Goddess) }\end{array}$ & $\begin{array}{c}\text { Первий солничий } \\
\text { свет - ЗОРЯ }\end{array}$ \\
\hline 149. & 5 & AeeSaH & $\begin{array}{c}\text { На сончева светлина } \\
\text { прва - НА ЗОРА }\end{array}$ & $\begin{array}{l}\text { Of Sun light first - OF } \\
\text { DAWN (of Isis) }\end{array}$ & $\begin{array}{c}\text { На первом солничном } \\
\text { свету - НА ЗОРЕ }\end{array}$ \\
\hline
\end{tabular}




\begin{tabular}{|c|c|c|c|c|c|}
\hline & $\begin{array}{l}\text { The original } \\
\text { Оригинал } \\
\text { Оригинал }\end{array}$ & $\begin{array}{c}\text { Cyrillic transcription } \\
\text { Кирилична транскрипција } \\
\text { Кириличная транскрипция } \\
\leftarrow\end{array}$ & $\begin{array}{c}\text { Contemporary Macedonian } \\
\text { Современ македонски } \\
\text { Современный македонский } \\
\text { язык } \\
\rightarrow\end{array}$ & $\begin{array}{l}\text { English } \\
\text { Англиски } \\
\text { Англиский } \\
\rightarrow\end{array}$ & $\begin{array}{c}\text { Russian } \\
\text { Руски } \\
\text { Русский язык } \\
\rightarrow\end{array}$ \\
\hline 150. & & e3AeeS aH & $\begin{array}{c}\text { На прва сончева } \\
\text { светлина (на зора) } \\
\text { младо сонце }\end{array}$ & $\begin{array}{l}\text { Of Sun light first (of dawn; } \\
\text { of Isis) (is) young son }\end{array}$ & $\begin{array}{c}\text { На первом солничном } \\
\text { свету (на заре) } \\
\text { молодое солнце }\end{array}$ \\
\hline 151. & & И(врП)eeS & Сончева светлина прв & Sun light he-first & $\begin{array}{c}\text { Первий солничий } \\
\text { свет }\end{array}$ \\
\hline 152 & & И(врП)eeS aH & $\begin{array}{c}\text { На сончева светлина прв } \\
\text { (Наочит) }\end{array}$ & $\begin{array}{l}\text { Of sun light he-first } \\
\text { (impressive) }\end{array}$ & $\begin{array}{c}\text { На первом солничном } \\
\text { свету (ярый) }\end{array}$ \\
\hline 153. & & И(врП)eeS aН ьЈаH & $\begin{array}{c}\text { Нај на сончева светлина } \\
\text { прв (Најнаочит) }\end{array}$ & $\begin{array}{l}\text { Best of sun light he-first } \\
\text { (most impressive) }\end{array}$ & $\begin{array}{l}\text { На самом первом } \\
\text { солничном свете } \\
\text { (Самий ярый) }\end{array}$ \\
\hline 154. & & $\begin{array}{c}\text { ьЈаН } \\
\text { аЦНеМИ(врП)еeS aH }\end{array}$ & $\begin{array}{l}\text { Најсветло име } \\
\text { (Фараон; Цар) }\end{array}$ & $\begin{array}{l}\text { Brightest name } \\
\text { (Pharaoh; Tsar) }\end{array}$ & $\begin{array}{c}\text { Самое первое на } \\
\text { солнечном свете имя } \\
\text { телотворенное } \\
\text { (Фараон; Царь) }\end{array}$ \\
\hline 155. & & $\begin{array}{c}\text { ьЈаН } \\
\text { оМњеМИ(врП)еeSaH }\end{array}$ & $\begin{array}{l}\text { Најсветла именувана } \\
\text { (Фараоница; Царица) }\end{array}$ & $\begin{array}{l}\text { Best of sun light she-first } \\
\text { name of great mother } \\
\text { (She-Pharaoh) }\end{array}$ & Царевня \\
\hline 156. & & $\begin{array}{c}\text { ьЈаН } \\
\text { еВИњеМИ(врП)еeSaH }\end{array}$ & $\begin{array}{c}\text { Најсветли именувани } \\
\text { (Фараониве) }\end{array}$ & $\begin{array}{c}\text { Best of sun light those first } \\
\text { names } \\
\text { (These Pharaohs) }\end{array}$ & Фараоне \\
\hline
\end{tabular}




\begin{tabular}{|c|c|c|c|c|c|}
\hline & $\begin{array}{l}\text { The original } \\
\text { Оригинал } \\
\text { Оригинал }\end{array}$ & $\begin{array}{c}\text { Cyrillic transcription } \\
\text { Кирилична транскрипција } \\
\text { Кириличная транскрипция } \\
\leftarrow\end{array}$ & $\begin{array}{c}\text { Contemporary Мacedonian } \\
\text { Современ македонски } \\
\text { Современный македонский } \\
\text { язык } \\
\rightarrow\end{array}$ & $\begin{array}{l}\text { English } \\
\text { Англиски } \\
\text { Англиский } \\
\rightarrow\end{array}$ & $\begin{array}{l}\text { Russian } \\
\text { Руски } \\
\text { Русский язык } \\
\rightarrow\end{array}$ \\
\hline 157. & & $\begin{array}{c}\text { ьЈаН } \\
\text { оМњеМИ(врП)еeSaH }\end{array}$ & $\begin{array}{c}\text { На Најсветла именувана } \\
\text { мајка (Фараоница мајка; } \\
\text { Царица мајка) }\end{array}$ & $\begin{array}{l}\text { Best of sun light she-first } \\
\text { name of great mother } \\
\text { (She-Pharaoh) }\end{array}$ & Царевня \\
\hline 158. & & отИеeS aH & $\begin{array}{l}\text { На сончевата светлина } \\
\text { првиот (Наочитиот) }\end{array}$ & $\begin{array}{l}\text { The best of sun light he- } \\
\text { first (the most impressive) }\end{array}$ & $\begin{array}{l}\text { Певий солнечного } \\
\text { света (самый ярый) }\end{array}$ \\
\hline 159. & & oМИ eeS aH & На сончева светлина име & Name of sun light & Имя солнечного луча \\
\hline \multicolumn{6}{|c|}{ И } \\
\hline 160. & & И & И; Прв; Врховен & I; First; Supreme & $\begin{array}{l}\text { И; Первый; } \\
\text { Вверховный }\end{array}$ \\
\hline 161. & & еѓи & Негови; Нивен & His; Their & Его; Их \\
\hline 162. & 2 & ееТШИ & Бара (Иште) & Request & Ищет \\
\hline 163. & & ьЈаПаН И & И потоа & And after & И потом \\
\hline 164. & 1 & оМИ & $\begin{array}{l}\text { Име; Имот; } \\
\text { Припадност }\end{array}$ & $\begin{array}{l}\text { Name; Property; } \\
\text { Belonging }\end{array}$ & $\begin{array}{c}\text { Имя; Имение; } \\
\text { Приндлежность }\end{array}$ \\
\hline
\end{tabular}




\begin{tabular}{|c|c|c|c|c|c|}
\hline & $\begin{array}{l}\text { The original } \\
\text { Оригинал } \\
\text { Оригинал }\end{array}$ & $\begin{array}{c}\text { Cyrillic transcription } \\
\text { Кирилична транскрипција } \\
\text { Кириличная транскрипция } \\
\leftarrow\end{array}$ & $\begin{array}{c}\text { Contemporary Macedonian } \\
\text { Современ македонски } \\
\text { Современный македонский } \\
\text { язык } \\
\rightarrow \\
\end{array}$ & $\begin{array}{c}\text { English } \\
\text { Англиски } \\
\text { Англиский } \\
\rightarrow \\
\end{array}$ & $\begin{array}{c}\text { Russian } \\
\text { Руски } \\
\text { Русский язык } \\
\rightarrow \\
\end{array}$ \\
\hline 165. & & уњ оМИ & Имоти & Properties & Имения \\
\hline 166. & & аЦНеМИ & Именец & Our name & Имя наше \\
\hline 167. & & НИ & Туѓинец; Странец & Foreigner; Stranger & Чужой; Иностранец \\
\hline 168. & & еНИ & Туѓинци; Странци & Foreigners; Strangers & Чужие; Иностранцы \\
\hline 169. & & оРИ & Xepoj & Hero & Герой \\
\hline 170. & & аЃоРИ & Воен херој & Hero of war & Военный герой \\
\hline 171. & $\mathcal{C}$ & аЃоРИ аЦед & Деца на воен херој & Children of hero of war & Дети военного героя \\
\hline 172. & & еМееСИаН & Најсемејство & Best (most) family & Самая изветная семья \\
\hline 173. & & ееЦИаН & Најценет; Срце & $\begin{array}{c}\text { Best (most) esteemed; } \\
\text { Heart }\end{array}$ & $\begin{array}{c}\text { Самый почотны; } \\
\text { Сердце }\end{array}$ \\
\hline 174. & & АИаН & На земја & On land & На земле \\
\hline 175. & & ИееЈееСьМаНАИаН & На сите мои земји & Of all my lands & $\begin{array}{l}\text { На моим всех } \\
\text { государствах }\end{array}$ \\
\hline 176. & & aНаН(врп)И & $\begin{array}{c}\text { Меч (Нож) симбол на } \\
\text { владетелот (фараонот) }\end{array}$ & $\begin{array}{l}\text { Sword - symbol of phar- } \\
\text { aoh's authority }\end{array}$ & $\begin{array}{l}\text { Сабля (Нож) символ } \\
\text { владетеля (фараона) }\end{array}$ \\
\hline
\end{tabular}




\begin{tabular}{|c|c|c|c|c|c|}
\hline & $\begin{array}{l}\text { The original } \\
\text { Оригинал } \\
\text { Оригинал }\end{array}$ & $\begin{array}{c}\text { Cyrillic transcription } \\
\text { Кирилична транскрипција } \\
\text { Кириличная транскрипция } \\
\leftarrow\end{array}$ & $\begin{array}{c}\text { Contemporary Масеdonian } \\
\text { Современ македонски } \\
\text { Современный македонский } \\
\text { язык } \\
\rightarrow\end{array}$ & $\begin{array}{l}\text { English } \\
\text { Англиски } \\
\text { Англиский } \\
\rightarrow\end{array}$ & $\begin{array}{c}\text { Russian } \\
\text { Руски } \\
\text { Русский язык } \\
\rightarrow\end{array}$ \\
\hline 177. & & аТаНаН(врп)И & $\begin{array}{c}\text { Мечот (Ножот) симбол } \\
\text { на владетелот (фараонот) }\end{array}$ & $\begin{array}{l}\text { The sword - the symbol } \\
\text { of pharaoh's authority }\end{array}$ & $\begin{array}{l}\text { Сабля (Нож) символ } \\
\text { владетеля (фараона) }\end{array}$ \\
\hline \multicolumn{6}{|c|}{$\mathbf{J}$} \\
\hline 178. & & bJ & $\mathrm{E}$ & Is & $\mathrm{E}$ \\
\hline 179. & & $\mathrm{HbJ}$ & Младенче; Јуниор & Offspring; Junior & Молоденец \\
\hline 180. & & аЦ НьЈ & Младенци; Јуниори & Offsprings; Juniors & Молоденци \\
\hline 181. & & еВоМ ьЈ & $\begin{array}{l}\text { Е мајка неприродна } \\
\text { (волчица) }\end{array}$ & $\begin{array}{l}\text { Is unnatural mother } \\
\text { (she-wolf) }\end{array}$ & $\begin{array}{l}\text { Мать неродная } \\
\text { (волчица) }\end{array}$ \\
\hline 182. & & аЦНоМьЈ & Потомци на волчицата & Ancestors of she-wolf & Волки \\
\hline 183. & & ееТШИ ьЈ & Ja (го) бара & Requests her & Ищет ее (его) \\
\hline 184. & & $\mathrm{~B}_{\mathrm{b}} \mathrm{J}$ & Јави (нареди) & Decreed & Дать указ \\
\hline 185. & & И(врП)ВьЈ & Јави првиот (фараонот) & (The) first decreed & Яви первий \\
\hline 186. & & оМВьJ & Јави Голема(та) Мајка & $\begin{array}{l}\text { (The) Great Mother } \\
\text { decreed }\end{array}$ & $\begin{array}{c}\text { Великая Мать дала } \\
\text { указ }\end{array}$ \\
\hline 187. & 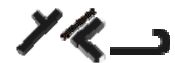 & енВ $\mathbf{b}$ & Јави врховникот & (The) supreme decreed & Верховний дал указ \\
\hline
\end{tabular}




\begin{tabular}{|c|c|c|c|c|c|}
\hline & $\begin{array}{l}\text { The original } \\
\text { Оригинал } \\
\text { Оригинал }\end{array}$ & $\begin{array}{c}\text { Cyrillic transcription } \\
\text { Кирилична транскрипција } \\
\text { Кириличная транскрипция } \\
\leftarrow\end{array}$ & $\begin{array}{c}\text { Contemporary Macedonian } \\
\text { Современ македонски } \\
\text { Современный македонский } \\
\text { язык } \\
\rightarrow\end{array}$ & $\begin{array}{c}\text { English } \\
\text { Англиски } \\
\text { Англиский } \\
\rightarrow\end{array}$ & $\begin{array}{c}\text { Russian } \\
\text { Руски } \\
\text { Русский язык } \\
\rightarrow\end{array}$ \\
\hline 188. & & оТВьЈ & Јави тој & He decreed & Он дал указ \\
\hline 189. & & oПоКь $\mathrm{J}$ & Е небесен град & Is heavenly city & Небесний город \\
\hline 190. & & оПоКьЈаН & $\begin{array}{l}\text { Најнебесен град } \\
\text { (Рај) }\end{array}$ & $\begin{array}{l}\text { Most heavenly city } \\
\text { (paradise; heaven) }\end{array}$ & Город высших небес \\
\hline 191. & & $\mathrm{yJ}$ & Нејзин & Hers & $\mathrm{Ee}$ \\
\hline 192. & & ИуЈ & Нејзини (нивни) & Hers (Theirs) & Ee (их) \\
\hline 193. & & И(врП) иЈ & Ни прв; Наши & Our first; Ours & Наши \\
\hline 194. & & ИуКуЈ & Нивни кумови & Their godfathers & Их \\
\hline 195. & & еЃу & $\begin{array}{c}\text { Луѓе (припадници; деца) } \\
\text { нејзини (на волчицата) }\end{array}$ & $\begin{array}{l}\text { Peoples (Children) of her } \\
\text { (of she-wolf) }\end{array}$ & $\begin{array}{c}\text { Люди } \\
\text { (принадлежащие; } \\
\text { дети) волков }\end{array}$ \\
\hline 196. & & едеЈ & Јаде & Eat & Кушать, кормится \\
\hline 197. & & ИоЛьЈ & Јадења & Meals & $\begin{array}{c}\text { Пища, блюда, } \\
\text { кушания }\end{array}$ \\
\hline 198. & & НьВеКеВоКаНьЈ & $\begin{array}{c}\text { Јунакот вековен } \\
\text { (Сотир; Спасител) }\end{array}$ & $\begin{array}{l}\text { Hero for centuries (ages) } \\
\text { (Soter; Saviour) }\end{array}$ & $\begin{array}{l}\text { Молодец / герой } \\
\text { вековный }\end{array}$ \\
\hline
\end{tabular}




\begin{tabular}{|c|c|c|c|c|c|}
\hline & $\begin{array}{l}\text { The original } \\
\text { Оригинал } \\
\text { Оригинал }\end{array}$ & $\begin{array}{c}\text { Cyrillic transcription } \\
\text { Кирилична транскрипција } \\
\text { Кириличная транскрипция } \\
\leftarrow\end{array}$ & $\begin{array}{c}\text { Contemporary Macedonian } \\
\text { Современ македонски } \\
\text { Современный македонский } \\
\text { язык } \\
\rightarrow\end{array}$ & $\begin{array}{c}\text { English } \\
\text { Англиски } \\
\text { Англиский } \\
\rightarrow\end{array}$ & $\begin{array}{c}\text { Russian } \\
\text { Руски } \\
\text { Русский язык } \\
\rightarrow\end{array}$ \\
\hline 199. & -1 & AeS eеЗНаН ьЈ & $\begin{array}{c}\text { Е наниза на сончева } \\
\text { светлина прва (на зората) }\end{array}$ & $\begin{array}{c}\text { Is necklace-of-necklaces } \\
\text { of first sun light }\end{array}$ & $\begin{array}{c}\text { Ожерелье-ожерельев } \\
\text { солнечного света }\end{array}$ \\
\hline 200. & & ooJ & $\begin{array}{c}\text { Врховен бог на Израел } \\
\text { (Евреите) }\end{array}$ & $\begin{array}{c}\text { Supreme God of Israel } \\
\text { (Jews) }\end{array}$ & Верхожний бог Еврев \\
\hline \multicolumn{6}{|c|}{$\mathbf{K}$} \\
\hline 201. & & $\mathrm{eK}$ & Како & How & Как \\
\hline 202. & & $\mathrm{oK}$ & Небесен & Heavenly & Небесний \\
\hline 203. & & $\mathrm{aK}$ & Змеј & Dragon; Serpent & Дракон \\
\hline 204. & & НиаК & Змеј туѓ; Непријател & Dragon foreign: Enemy & Дракон чужой, Враг \\
\hline 205. & & $\mathrm{eBaK}$ & Змеј отелотворен & Dragon embodied & $\begin{array}{c}\text { Дракон } \\
\text { отелотворений }\end{array}$ \\
\hline 206. & & eeJaHaK & Кани & Invite & Приглашает \\
\hline 207. & & yK & Кум & Godfather & Кресний \\
\hline 208. & & $\mathrm{BeK}$ & Крв & Blood & Кровь \\
\hline 209. & & ИНееКаН & $\begin{array}{c}\text { На наши роднини } \\
\text { (по крв) }\end{array}$ & $\begin{array}{l}\text { Of our relatives } \\
\text { (blood related) }\end{array}$ & $\begin{array}{c}\text { Нашим } \\
\text { соотечественникам } \\
\text { (по кровь) }\end{array}$ \\
\hline
\end{tabular}




\begin{tabular}{|c|c|c|c|c|c|}
\hline & $\begin{array}{l}\text { The original } \\
\text { Оригинал } \\
\text { Оригинал }\end{array}$ & $\begin{array}{c}\text { Cyrillic transcription } \\
\text { Кирилична транскрипција } \\
\text { Кириличная транскрипция } \\
\leftarrow\end{array}$ & $\begin{array}{c}\text { Contemporary Macedonian } \\
\text { Современ македонски } \\
\text { Современный македонский } \\
\text { язык } \\
\rightarrow\end{array}$ & $\begin{array}{c}\text { English } \\
\text { Англиски } \\
\text { Англиский } \\
\rightarrow\end{array}$ & $\begin{array}{c}\text { Russian } \\
\text { Руски } \\
\text { Русский язык } \\
\rightarrow\end{array}$ \\
\hline 210. & & eBeKoK & Куќиве & These houses & Дома \\
\hline \multicolumn{6}{|c|}{$\boldsymbol{I}$} \\
\hline 211. & & оТЛ & Лето (годишно време) & Summer (season of year) & Лето (время года) \\
\hline 212. & & ИоТЛ & Лета & Summers & Лето \\
\hline 213. & $V \lambda$ & аЧЛ & Сончев зрак & Sun ray & Небесий лучь \\
\hline 214. & $\lambda$ & И(врП)Л & Обнова; Прв & Renewal; First one & Обновление \\
\hline 215. & & АЛ & $\begin{array}{c}\text { Храбар; силен; } \\
\text { бестрашен (Лав) }\end{array}$ & $\begin{array}{c}\text { Brave; Strong; Fearless } \\
\text { (Lion) }\end{array}$ & $\begin{array}{l}\text { Храберий; сильний; } \\
\text { бесстрашний (Лев) }\end{array}$ \\
\hline 216. & & аЦаЛ & $\begin{array}{c}\text { Лавови } \\
\text { (Македонски војници) }\end{array}$ & $\begin{array}{c}\text { Lions embodied } \\
\text { (Macedonian soldiers) }\end{array}$ & $\begin{array}{c}\text { Воплощение львы } \\
\text { (военни) }\end{array}$ \\
\hline 217. & & eЛ & Висока титула & High title & Високой титуль \\
\hline 218. & & АеЛ & Муза на вајарите & Muse of sculptors & Муза скульпторов \\
\hline 219. & & АеЛ аН & Статуа & Statue & Статуа \\
\hline 220. & & ееЗоЛаН & Нарез; Цртеж & Carving; Drawing & Картина; Рисунок \\
\hline
\end{tabular}




\begin{tabular}{|c|c|c|c|c|c|}
\hline & $\begin{array}{l}\text { The original } \\
\text { Оригинал } \\
\text { Оригинал }\end{array}$ & $\begin{array}{c}\text { Cyrillic transcription } \\
\text { Кирилична транскрипција } \\
\text { Кириличная транскрипция } \\
\leftarrow \\
\end{array}$ & $\begin{array}{c}\text { Contemporary Macedonian } \\
\text { Современ македонски } \\
\text { Современный македонский } \\
\text { язык } \\
\rightarrow \\
\rightarrow\end{array}$ & $\begin{array}{l}\text { English } \\
\text { Англиски } \\
\text { Англиский } \\
\rightarrow\end{array}$ & $\begin{array}{c}\text { Russian } \\
\text { Руски } \\
\text { Русский язык } \\
\rightarrow\end{array}$ \\
\hline 221. & r< & оТеВееЖ ееЗоЛаН & $\begin{array}{l}\text { Нарез живиот; } \\
\text { Живата слика }\end{array}$ & Live carving; Live image & $\begin{array}{l}\text { Живая картина; } \\
\text { Живой рисунок }\end{array}$ \\
\hline 222. & l $v$ & оТаЦ иШВВ ееЗоЛаН & $\begin{array}{c}\text { Нарез во камен тврд } \\
\text { (гранит) }\end{array}$ & $\begin{array}{l}\text { Drawing into stone hard } \\
\text { (granite) }\end{array}$ & $\begin{array}{c}\text { Картина на твердим } \\
\text { камне (гранит) }\end{array}$ \\
\hline 223. & Vד & аЧ ьЈ ењ уЛ & $\mid \begin{array}{c}\text { На нејзините следбеници } \\
\text { е небесна (сончева) } \\
\text { искра }\end{array}$ & $\begin{array}{l}\text { Is (sun) sparkle to her fol- } \\
\text { lowers (worshipers) }\end{array}$ & $\begin{array}{c}\text { Она лучь небесний } \\
\text { для своих стороников }\end{array}$ \\
\hline 224. & $?$ & еЃул & Луѓе од Египет & $\begin{array}{l}\text { People from Egypt } \\
\text { (Egyptians) }\end{array}$ & Люди Египта \\
\hline \multicolumn{6}{|c|}{ Љ } \\
\hline 225. & & аЃуљ & Луѓе војници & People soldiers & Военние люди \\
\hline 226. & 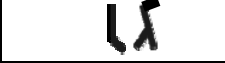 & аТуљ & Лути & Hot peppery & Сердиты \\
\hline 227. & $V \rightarrow / / X$ & аЧ ьЈ ењ уљ & Нејзина е сончева искра & Is her sun spark & Ее солнечний лучь \\
\hline 228. & $<1<5 X$ & еВоТ еВоБуљ & Возљубениве тие & Those beloved & Возлюбление эти \\
\hline \multicolumn{6}{|c|}{ M } \\
\hline 229. & l & $\mathrm{oM}$ & Голема (небесна) Мајка & Great (Heavenly) Mother & $\begin{array}{c}\text { Великая (Небесная) } \\
\text { Мать }\end{array}$ \\
\hline
\end{tabular}




\begin{tabular}{|c|c|c|c|c|c|}
\hline & $\begin{array}{l}\text { The original } \\
\text { Оригинал } \\
\text { Оригинал }\end{array}$ & $\begin{array}{c}\text { Cyrillic transcription } \\
\text { Кирилична транскрипција } \\
\text { Кириличная транскрипция } \\
\leftarrow\end{array}$ & $\begin{array}{c}\text { Contemporary Macedonian } \\
\text { Современ македонски } \\
\text { Современный македонский } \\
\text { язык } \\
\rightarrow \\
\end{array}$ & $\begin{array}{l}\text { English } \\
\text { Англиски } \\
\text { Англиский } \\
\rightarrow \\
\end{array}$ & $\begin{array}{c}\text { Russian } \\
\text { Руски } \\
\text { Русский язык } \\
\rightarrow\end{array}$ \\
\hline 230 . & & ooM & $\begin{array}{c}\text { Голема (земна) Мајка } \\
\text { (МА) }\end{array}$ & Great mother on earth & $\begin{array}{c}\text { Великая земная мать } \\
\text { (МА) }\end{array}$ \\
\hline 231. & & $\mathrm{eM}$ & Moe; Jac & Mine; I & Moe, Я \\
\hline 232. & & ьМ & Ние & We & Мы \\
\hline 233. & & аЦом & $\begin{array}{c}\text { Отелотворување на } \\
\text { Голема Мајка (епитет на } \\
\text { прислужничка во цере- } \\
\text { монија посветена на } \\
\text { боговите) }\end{array}$ & $\begin{array}{l}\text { Embodiment of the Great } \\
\text { Mother (epithet of a young } \\
\text { girl basket carrier on a } \\
\text { festival of gods) }\end{array}$ & $\begin{array}{c}\text { Воплащение Великой } \\
\text { матери } \\
\text { (слушкиня церемоний } \\
\text { посвещеним богам) }\end{array}$ \\
\hline 234. & & Аедом & $\begin{array}{c}\text { Голема Мајка Божица } \\
\text { прва (Врховна) }\end{array}$ & $\begin{array}{l}\text { Great Heavenly Mother } \\
\text { Goddess Supreme }\end{array}$ & $\begin{array}{c}\text { Великая мать Богиня } \\
\text { первая }\end{array}$ \\
\hline 235. & & НиТед оМаН & $\begin{array}{c}\text { На Голема Мајка } \\
\text { божествата ни }\end{array}$ & $\begin{array}{c}\text { Deities of Great Heavenly } \\
\text { mother of ours }\end{array}$ & $\begin{array}{c}\text { Божества великой } \\
\text { матери }\end{array}$ \\
\hline 236. & $\lambda$ & ЛоМ & Голема Мајка ле & Great Heavenly Mother is & Великая мать \\
\hline 237. & & оЛом & Се моли & Is praying & Молится \\
\hline 238. & & ИоЛоМ & Се молат & Are praying & Молятся \\
\hline 239. & & e3oM & Мајчино Младо сонце & Mother's young sun & $\begin{array}{c}\text { Великая мать } \\
\text { Молодое солнце }\end{array}$ \\
\hline
\end{tabular}




\begin{tabular}{|c|c|c|c|c|c|}
\hline & $\begin{array}{l}\text { The original } \\
\text { Оригинал } \\
\text { Оригинал }\end{array}$ & $\begin{array}{c}\text { Cугіllic transcription } \\
\text { Кирличчна трансрипција } \\
\text { Кириличная транскрипция } \\
\leftarrow \\
\end{array}$ & $\begin{array}{c}\text { Contemporary Macedonian } \\
\text { Современ македонски } \\
\text { Современный македонский } \\
\text { язык } \\
\rightarrow \\
\end{array}$ & $\begin{array}{c}\text { English } \\
\text { Англиски } \\
\text { Англиский } \\
\rightarrow \\
\end{array}$ & $\begin{array}{c}\text { Russian } \\
\text { Руски } \\
\text { Русский язык } \\
\rightarrow \\
\end{array}$ \\
\hline 240. & $<$ & eBoM & $\begin{array}{c}\text { Голема Мајка } \\
\text { неприродна (вештачка) - } \\
\text { Волчица }\end{array}$ & $\begin{array}{c}\text { Great Heavenly Mother } \\
\text { unnatural }\end{array}$ & $\begin{array}{c}\text { Великая Мать } \\
\text { неродная - Волчица }\end{array}$ \\
\hline 241. & & aКoM & Голема Мајка змеј & $\begin{array}{c}\text { Great Heavenly Mother } \\
\text { dragon }\end{array}$ & Великая Мать змей \\
\hline 242. & & eВаКоМ & $\begin{array}{c}\text { Голема Мајка змеј } \\
\text { неприродна }\end{array}$ & $\begin{array}{l}\text { Great Heavenly Mother } \\
\text { dragon unnatural }\end{array}$ & $\begin{array}{c}\text { Великая Мать } \\
\text { неродная дракон }\end{array}$ \\
\hline 243. & 7 & eḰoM & Моќни & Mighty & Мочь \\
\hline 244. & 0 & eЃoM & $\begin{array}{l}\text { Мајчини луѓе - } \\
\text { МАКЕДОНЦИ }\end{array}$ & $\begin{array}{l}\text { Fellows of Great Heavenly } \\
\text { Mother - MACEDONIAN }\end{array}$ & $\begin{array}{l}\text { Люди Великой } \\
\text { Матери - } \\
\text { МАКЕДОНЦИ }\end{array}$ \\
\hline 245. & $V$ & аЦаПоМ & $\begin{array}{c}\text { Македонци од Горна } \\
\text { Македонија }\end{array}$ & $\begin{array}{c}\text { Macedonians from Upper } \\
\text { Macedonia (Paionians) }\end{array}$ & $\begin{array}{c}\text { Македонци Верхней } \\
\text { Македонии }\end{array}$ \\
\hline 246. & $\mu 1$ & оЖоМ & Маж & Men & Муж \\
\hline 247. & $|r|$ & ИоЖоМ & Мажи & Mens & Мущчини \\
\hline 248. & 11 & oMoM & $\begin{array}{l}\text { Голема Мајка } \\
\text { Голема Мајка }\end{array}$ & $\begin{array}{l}\text { Great Heavenly Mother } \\
\text { Great heavenly mother }\end{array}$ & $\begin{array}{l}\text { Великая Мать } \\
\text { Великая Мать }\end{array}$ \\
\hline 249. & 1 & ењоМИ ИоМоМ & $\begin{array}{l}\text { Мајчини сопствени } \\
\text { имоти (лозја) }\end{array}$ & Vineyards & Виноградник \\
\hline
\end{tabular}




\begin{tabular}{|c|c|c|c|c|c|}
\hline & $\begin{array}{l}\text { The original } \\
\text { Оригинал } \\
\text { Оригинал }\end{array}$ & $\begin{array}{c}\text { Cyrillic transcription } \\
\text { Кирилична транскрипција } \\
\text { Кириличная транскрипция } \\
\leftarrow\end{array}$ & $\begin{array}{c}\text { Contemporary Macedonian } \\
\text { Современ македонски } \\
\text { Современный македонский } \\
\text { язык } \\
\rightarrow \\
\end{array}$ & $\begin{array}{c}\text { English } \\
\text { Англиски } \\
\text { Англиский } \\
\rightarrow \\
\end{array}$ & $\begin{array}{c}\text { Russian } \\
\text { Руски } \\
\text { Русский язык } \\
\rightarrow \\
\end{array}$ \\
\hline 250. & & ьЈoM & Moj & My & Мой \\
\hline 251. & & ИоМ & Мои (сопствени) & My (own) & Мои \\
\hline 252. & & ьМом аН & На мој(от) & Of my & На майом \\
\hline 253. & & eeJoM & Мои & Mine & Мои \\
\hline 254. & & oJoM & Мојот & Mine & Мой \\
\hline 255. & & ИооЈоМ & Моите & Mine & Мои \\
\hline 256. & & eMoM & На мојот & Of my & На мой \\
\hline 257. & & недЕ оTeeS оTоM & $\begin{array}{c}\text { Данок што се плаќал во } \\
\text { Египет во тој период од } \\
\text { имоти на Големата } \\
\text { Мајка (лозјата) и } \\
\text { изнесувал еден сад со } \\
\text { вино од } 1 \text { зора (мерка за } \\
\text { површина која } \\
\text { приближно изнесувала } 1 \\
\text { акра, односно околу } \\
4000 \mathrm{~m}^{2}\end{array}$ & $\begin{array}{l}\text { The tax that was payed in } \\
\text { the Ancient Egypt in the } \\
\text { Ptolemaic period in the } \\
\text { quantity of } 1 \text { vessel of vine } \\
\text { from } 1 \text { aurora (measure for } \\
\text { land with a value of } 1 \text { acre, } \\
\text { or around } 4000 \mathrm{~m}^{2} \text { ) }\end{array}$ & $\begin{array}{c}\text { Налог, который } \\
\text { оплачивался в Древ- } \\
\text { нем Египте в период } \\
\text { Птолемеев в коли- } \\
\text { честве } 1 \text { судно вино- } \\
\text { града от } 1 \text { сияния } \\
\text { (земельний размер со } \\
\text { значением } 1 \text { акр, или } \\
\text { около } 4000 \mathrm{~m}^{2} \text { ) }\end{array}$ \\
\hline 258. & & ИеМ аН & На мои & Of mine's & На моих \\
\hline
\end{tabular}




\begin{tabular}{|c|c|c|c|c|c|}
\hline & $\begin{array}{l}\text { The original } \\
\text { Оригинал } \\
\text { Оригинал }\end{array}$ & $\begin{array}{c}\text { Cyrillic transcription } \\
\text { Кирилична транскрипција } \\
\text { Кириличная транскрипция } \\
\leftarrow\end{array}$ & $\begin{array}{c}\text { Contemporary Macedonian } \\
\text { Современ македонски } \\
\text { Современный македонский } \\
\text { язык } \\
\rightarrow\end{array}$ & $\begin{array}{c}\text { English } \\
\text { Англиски } \\
\text { Англиский } \\
\rightarrow\end{array}$ & $\begin{array}{c}\text { Russian } \\
\text { Руски } \\
\text { Русский язык } \\
\rightarrow\end{array}$ \\
\hline 259. & & oМ ИеМ аН & На мои Голема Мајка & $\begin{array}{l}\text { Great Heavenly Mother } \\
\text { of mine }\end{array}$ & $\begin{array}{c}\text { Моим она Великая } \\
\text { Мать }\end{array}$ \\
\hline 260. & & Н ИеМ аН & На мои ни & Of mine & Нам \\
\hline 261. & & ee3 eM & $\begin{array}{c}\text { Моја месечева (ладна) } \\
\text { светлина; Мој дух }\end{array}$ & $\begin{array}{l}\text { My moon (cold) light; } \\
\text { My spirit }\end{array}$ & $\begin{array}{l}\text { Мой лунний (холод- } \\
\text { ний) свет; Мой дух }\end{array}$ \\
\hline 262. & & aЧеМ & Манџа & Food & Блюда \\
\hline 263. & 4 & ШеВИоМ & Измиваш & Wash out & Вымить \\
\hline \multicolumn{6}{|c|}{$\mathbf{H}$} \\
\hline 264. & & $\mathrm{H}$ & Ни & Our & Нам \\
\hline 265. & & $\mathrm{OOH}$ & $\begin{array}{c}\text { Врховен (небесен) } \\
\text { господар ни }\end{array}$ & $\begin{array}{c}\text { Supreme (heavenly) Lord } \\
\text { of ours }\end{array}$ & $\begin{array}{l}\text { Верховний (небес- } \\
\text { ний) наш государь }\end{array}$ \\
\hline 266. & & АИ Н & Земја ни & Our land & Наша земля \\
\hline 267. & 6 & $\mathrm{aH}$ & $\mathrm{Ha}$ & On & $\mathrm{Ha}$ \\
\hline 268. & & ИеРаН & Знаци (Рецки; Нарези) & Signs & Знаки \\
\hline
\end{tabular}




\begin{tabular}{|c|c|c|c|c|c|}
\hline & $\begin{array}{l}\text { The original } \\
\text { Оригинал } \\
\text { Оригинал }\end{array}$ & $\begin{array}{c}\text { Cyrillic transcription } \\
\text { Кирилична транскрипција } \\
\text { Кириличная транскрипция } \\
\leftarrow\end{array}$ & $\begin{array}{c}\text { Contemporary Macedonian } \\
\text { Современ македонски } \\
\text { Современный македонский } \\
\text { язык } \\
\rightarrow \\
\end{array}$ & $\begin{array}{c}\text { English } \\
\text { Англиски } \\
\text { Англиский } \\
\rightarrow\end{array}$ & $\begin{array}{c}\text { Russian } \\
\text { Руски } \\
\text { Русский язык } \\
\rightarrow\end{array}$ \\
\hline 269. & & аЦИеРаН & $\begin{array}{c}\text { Напишани знаци } \\
\text { (Писмо) }\end{array}$ & $\begin{array}{l}\text { Signs engraved } \\
\text { (Script) }\end{array}$ & $\begin{array}{c}\text { Писмение знаки } \\
\text { (письмо) }\end{array}$ \\
\hline 270 . & & ИeeS ИеРаН & $\begin{array}{l}\text { Сончеви знаци } \\
\text { (свети знаци) }\end{array}$ & $\begin{array}{l}\text { Sun's Signs } \\
\text { (holy signs) }\end{array}$ & $\begin{array}{c}\text { Знаки солнечнего } \\
\text { света }\end{array}$ \\
\hline 271. & & $\mathrm{eH}$ & Врховник (титула); Врв & Supreme (title); Peak & Верхивный \\
\hline 272. & & $\mathrm{a} \Gamma \dot{\Gamma} \mathrm{H}$ & Врховен командант & Supreme commander & $\begin{array}{l}\text { Верховный } \\
\text { командант }\end{array}$ \\
\hline 273. & & ee3HaH & Наниза & Necklace of necklaces & Ожереле \\
\hline 274. & & eḰeHaH & Месечно; Секој месец & Monthly; Every month & Каждий месяц \\
\hline 275. & & oМyH & Долу & Down & Внизу \\
\hline 276. & & оМуНьЈаН & Најдолу & Most down; Bottom & Самий низ \\
\hline \multicolumn{6}{|c|}{ Њ } \\
\hline 277. & & eСeЊ & Носи & Brings & Несет \\
\hline 278. & $\int$ & оМуњ & На неа & To her & Ha ee \\
\hline \multicolumn{6}{|c|}{$\mathbf{O}$} \\
\hline
\end{tabular}




\begin{tabular}{|c|c|c|c|c|c|}
\hline & $\begin{array}{l}\text { The original } \\
\text { Оригинал } \\
\text { Оригинал }\end{array}$ & $\begin{array}{c}\text { Cугіllic transcription } \\
\text { Кирличчна трансрипција } \\
\text { Кириличная транскрипция } \\
\leftarrow \\
\end{array}$ & $\begin{array}{c}\text { Contemporary Macedonian } \\
\text { Современ македонски } \\
\text { Современный македонский } \\
\text { язык } \\
\rightarrow \\
\end{array}$ & $\begin{array}{c}\text { English } \\
\text { Англиски } \\
\text { Англиский } \\
\rightarrow \\
\end{array}$ & $\begin{array}{c}\text { Russian } \\
\text { Руски } \\
\text { Русский язык } \\
\rightarrow \\
\end{array}$ \\
\hline \multicolumn{6}{|c|}{$\Pi$} \\
\hline 279. & $\mathbf{L}$ & aП & Горе; Горен & Up; Upper & Вверх, верхный \\
\hline 280. & L & ИаП & Горни & Upper & Верхные \\
\hline 281. & IIL & оТИаП & Горните & The Upper & Верхные \\
\hline 282. & 1 & НаП & Горнион ни; Господин & Our higher; Mister & Вверхные наши \\
\hline 283. & $\% \mathrm{~L}$ & аНаП & Горна; Госпоѓа & Madam & Вверхная, Госпожа \\
\hline 284. & LL & аПаП & $\begin{array}{l}\text { Папа; (Горен горен - } \\
\text { Врховен; Свет) }\end{array}$ & Upper; supreme & Верхный; вверхний \\
\hline 285. & & оМНаП & Горнион ни мајчин & $\begin{array}{l}\text { The Upper } \\
\text { of Great Heavenly Mother }\end{array}$ & $\begin{array}{l}\text { Наш верховный от } \\
\text { большой матери }\end{array}$ \\
\hline 286. & & еeСaПаН & На горнион се & Belonging to the Upper & $\begin{array}{c}\text { На верхнему } \\
\text { принадлежать }\end{array}$ \\
\hline 287. & 4 & ИееСаПаН & На горнион сите & $\begin{array}{l}\text { All men belonging to the } \\
\text { Upper }\end{array}$ & $\begin{array}{l}\text { На верхнему все } \\
\text { принадежать }\end{array}$ \\
\hline 288. & $\bar{L}$ & АИ $а П \mathrm{aH}$ & На Горна земја & Of Upper Land & На верхней земли \\
\hline 289. & & оТАИ аП аН & На Горната земја & Of the Upper Land & На верхней земли \\
\hline
\end{tabular}




\begin{tabular}{|c|c|c|c|c|c|}
\hline & $\begin{array}{l}\text { The original } \\
\text { Оригинал } \\
\text { Оригинал }\end{array}$ & $\begin{array}{c}\text { Cyrillic transcription } \\
\text { Кирилична транскрипција } \\
\text { Кириличная транскрипция } \\
\leftarrow\end{array}$ & $\begin{array}{c}\text { Contemporary Macedonian } \\
\text { Современ македонски } \\
\text { Современный македонский } \\
\text { язык } \\
\rightarrow \\
\end{array}$ & $\begin{array}{l}\text { English } \\
\text { Англиски } \\
\text { Англиский } \\
\rightarrow \\
\end{array}$ & $\begin{array}{c}\text { Russian } \\
\text { Руски } \\
\text { Русский язык } \\
\rightarrow \\
\end{array}$ \\
\hline 290. & & ьЈаП аH & И потоа & And after that & И потом \\
\hline 291. & & ИиПаН & Да се напие & To drink & Выпить \\
\hline 292. & & оП & Град & City & Город \\
\hline 293. & & оТоП & Градот & The city & Город \\
\hline 294. & & оТоП АеД аН & $\begin{array}{c}\text { На Божица Врховна } \\
\text { градот (Теба - Египет) } \\
\text { (Пела - Македонија) }\end{array}$ & $\begin{array}{c}\text { City of the Great Heavenly } \\
\text { Mother (Theba - Ancient } \\
\text { Egypt) (Pela - Ancient } \\
\text { Macedonia) }\end{array}$ & $\begin{array}{c}\text { Город большой } \\
\text { матери (Теба - } \\
\text { Египет) (Пела - } \\
\text { Македония) }\end{array}$ \\
\hline 295. & & еВоМьЈ оТоП ооГ & $\begin{array}{c}\text { На Творец градот } \\
\text { на волците (Lycopolis - } \\
\text { Египет) }\end{array}$ & $\begin{array}{l}\text { City of Creator of wolfs } \\
\text { (Lycopolis - Egypt) }\end{array}$ & $\begin{array}{c}\text { Город создателя } \\
\text { волков }\end{array}$ \\
\hline 296. & & оТоП А ьуЃ аН & $\begin{array}{c}\text { На Убава земја (назив } \\
\text { за Египет на древните } \\
\text { Македонци) прв (главен) } \\
\text { град (Александрија) }\end{array}$ & $\begin{array}{l}\text { Of Beautiful Land (name } \\
\text { of Egypt in Ancient Mace- } \\
\text { donian Language) first } \\
\text { (main) city (Alexandria) }\end{array}$ & $\begin{array}{c}\text { На красивой земли } \\
\text { (так називали Египет } \\
\text { древние Македонци) } \\
\text { первий город (столи- } \\
\text { ца) (Александрия) }\end{array}$ \\
\hline \multicolumn{6}{|c|}{$\mathbf{P}$} \\
\hline 297. & م & oP & $\begin{array}{c}\text { Владетелска куќа; } \\
\text { Владетелско семејство }\end{array}$ & $\begin{array}{l}\text { Ruler's House; } \\
\text { Ruling dynasty }\end{array}$ & $\begin{array}{c}\text { Дом; Династия } \\
\text { владетелев }\end{array}$ \\
\hline
\end{tabular}




\begin{tabular}{|c|c|c|c|c|c|}
\hline & $\begin{array}{l}\text { The original } \\
\text { Оригинал } \\
\text { Оригинал }\end{array}$ & $\begin{array}{c}\text { Cyrillic transcription } \\
\text { Кирилична транскрипција } \\
\text { Кириличная транскрипция } \\
\leftarrow\end{array}$ & $\begin{array}{c}\text { Contemporary Мacedonian } \\
\text { Современ македонски } \\
\text { Современный македонский } \\
\text { язык } \\
\rightarrow\end{array}$ & $\begin{array}{l}\text { English } \\
\text { Англиски } \\
\text { Англиский } \\
\rightarrow\end{array}$ & $\begin{array}{c}\text { Russian } \\
\text { Руски } \\
\text { Русский язык } \\
\rightarrow\end{array}$ \\
\hline 298. & & $\mathrm{AИ} \mathrm{оР} \mathrm{aH}$ & $\begin{array}{c}\text { На владетелска куќа } \\
\text { на земјата }\end{array}$ & $\begin{array}{l}\text { Of dynasty (house of rul- } \\
\text { ers) of the land }\end{array}$ & $\begin{array}{c}\text { Династия (дом } \\
\text { владетеля) на земле }\end{array}$ \\
\hline 299. & & $\begin{array}{c}\text { АИоРаН } \\
\text { аЦНеМИееSаНьЈаН }\end{array}$ & $\begin{array}{c}\text { На владетелска куќа } \\
\text { на земја (држава) } \\
\text { на најсветло име }\end{array}$ & $\begin{array}{l}\text { Ruling house (dynasty) } \\
\text { of pharaoh's country }\end{array}$ & Дом владетеля \\
\hline 300. & & ееЦИаН АИоРаН & $\begin{array}{c}\text { Куќа на (најценетото) на } \\
\text { срцето (тело) }\end{array}$ & $\begin{array}{c}\text { House of (most valuable) } \\
\text { heart (body) }\end{array}$ & $\begin{array}{c}\text { Дом (самого } \\
\text { драгоценого) сердца } \\
\text { (тело) }\end{array}$ \\
\hline 301. & & $\begin{array}{c}\text { АИоРаН } \\
\text { АИоРаН ееЦИаН }\end{array}$ & $\begin{array}{c}\text { Куќа на телото - } \\
\text { погребна просторија } \\
\text { (ковчег) }\end{array}$ & $\begin{array}{l}\text { House of body - burial } \\
\text { chamber (casket) }\end{array}$ & $\begin{array}{c}\text { Дом тела - помеше- } \\
\text { ние для хранения } \\
\text { (ковчег/саркофаг) }\end{array}$ \\
\hline 302. & & HoP & Куќа ни; семејство ни & Our house; Our family & Наш дом; наша семья \\
\hline 303. & $<$ & еВьШаН НоР & $\begin{array}{c}\text { Куќа ни на свештенство } \\
\text { градба - државна } \\
\text { канцеларија }\end{array}$ & $\begin{array}{l}\text { Our house of priesthood } \\
\text { building - State office }\end{array}$ & $\begin{array}{l}\text { Дом священства - } \\
\text { государственное } \\
\text { учереждение }\end{array}$ \\
\hline 304. & $<P$ & eBoP & Молња; Ровја & Lightning & Молнія \\
\hline 305. & & eP & Рецка & Carve & Черта \\
\hline
\end{tabular}




\begin{tabular}{|c|c|c|c|c|c|}
\hline & $\begin{array}{l}\text { The original } \\
\text { Оригинал } \\
\text { Оригинал }\end{array}$ & $\begin{array}{c}\text { Cyrillic transcription } \\
\text { Кирилична транскрипција } \\
\text { Кириличная транскрипция } \\
\leftarrow\end{array}$ & $\begin{array}{c}\text { Contemporary Macedonian } \\
\text { Современ македонски } \\
\text { Современный македонский } \\
\text { язык } \\
\rightarrow\end{array}$ & $\begin{array}{l}\text { English } \\
\text { Англиски } \\
\text { Англиский } \\
\rightarrow\end{array}$ & $\begin{array}{c}\text { Russian } \\
\text { Руски } \\
\text { Русский язык } \\
\rightarrow\end{array}$ \\
\hline 306. & 8 & ooP & Свет запис & Heavenly Inscription & Запись небесний \\
\hline 307. & & аЦооРаН & На запишан свет запис & $\begin{array}{l}\text { Of engraved heavenly In- } \\
\text { scription }\end{array}$ & $\begin{array}{c}\text { Написанная небесная } \\
\text { запись }\end{array}$ \\
\hline 308. & & еНаЦооРаН & На светине записи & $\begin{array}{c}\text { Those heavenly inscrip- } \\
\text { tions }\end{array}$ & Написанные записи \\
\hline 309. & & $\begin{array}{l}\text { оТаЦооРаН } \\
\text { ееТШ А аH }\end{array}$ & Нашите свети записи & Our heavenly inscriptions & Наш твердий запись \\
\hline 310. & & еВьМаР аН & На рамењава & On these shoulders & На плечах \\
\hline \multicolumn{6}{|c|}{$\mathbf{C}$} \\
\hline 311. & & иС & Собир; Совет & Assembly; Council & Сбор; Совет \\
\hline 312. & & аЦееЖиС аН & На собир на жреци & Assembly of prophets & Совет жрецов \\
\hline 313. & & ооЈаНиС & $\begin{array}{l}\text { Собир на Јоо (богот } \\
\text { на Израел) - Синај }\end{array}$ & $\begin{array}{l}\text { Assembly of Ja (supreme } \\
\text { God of Israel) - Sinai }\end{array}$ & $\begin{array}{l}\text { Сбор у Йоо (у бога } \\
\text { Израля) - Синай }\end{array}$ \\
\hline 314. & & еВИееС ооЈаНиС аН & На Синај сиве & In Sinai all & $\begin{array}{c}\text { Во всех (храмах) } \\
\text { Синая }\end{array}$ \\
\hline
\end{tabular}




\begin{tabular}{|c|c|c|c|c|c|}
\hline & $\begin{array}{l}\text { The original } \\
\text { Оригинал } \\
\text { Оригинал }\end{array}$ & $\begin{array}{c}\text { Cyrillic transcription } \\
\text { Кирилична транскрипција } \\
\text { Кириличная транскрипция } \\
\leftarrow\end{array}$ & $\begin{array}{c}\text { Contemporary Macedonian } \\
\text { Современ македонски } \\
\text { Современный македонский } \\
\text { язык } \\
\rightarrow \\
\end{array}$ & $\begin{array}{c}\text { English } \\
\text { Англиски } \\
\text { Англиский } \\
\rightarrow\end{array}$ & $\begin{array}{c}\text { Russian } \\
\text { Руски } \\
\text { Русский язык } \\
\rightarrow \\
\end{array}$ \\
\hline 315. & & $\mathrm{oMaC}$ & Само; Исклучително & Only; Exclusive & $\begin{array}{c}\text { Только, } \\
\text { исключительно }\end{array}$ \\
\hline 316. & & AyC & Свој & Own & Свой \\
\hline 317. & & eeC & Cè & Everything & Bcë \\
\hline 318. & & И(врП) еeС aН & На сѐ е прв; на сите & Is first of everything & На всех верховный \\
\hline 319. & & $\mathrm{AИ} \mathrm{еeC} \mathrm{aH}$ & На сета земја & Of all land & На всей земли \\
\hline 320. & & $\mathrm{eB}$ eeC aH & $\begin{array}{l}\text { На секој мајстор } \\
\text { (градител) }\end{array}$ & $\begin{array}{l}\text { Of every workman } \\
\text { (builder) }\end{array}$ & На каждом мастере \\
\hline 321. & & ИеВ eeC aH & $\begin{array}{l}\text { На сите мајстори } \\
\text { (градители) }\end{array}$ & $\begin{array}{l}\text { Of all work men } \\
\text { (builders) }\end{array}$ & На всех мастерах \\
\hline 322. & & иКееС & Секој & Everybody & Каждий \\
\hline 323. & & $\mathrm{H}$ eH eeC & На сѐ врховник ни & $\begin{array}{c}\text { The Supreme } \\
\text { of everythings of ours }\end{array}$ & Каждому главний \\
\hline 324. & 1 & oTeeC & Сите & All & Bce \\
\hline 325. & & eMeeC & Семејство; Семе & Family; Seed & Семья; Семян \\
\hline
\end{tabular}




\begin{tabular}{|c|c|c|c|c|c|}
\hline & $\begin{array}{l}\text { The original } \\
\text { Оригинал } \\
\text { Оригинал }\end{array}$ & $\begin{array}{c}\text { Cyrillic transcription } \\
\text { Кирилична транскрипција } \\
\text { Кириличная транскрипция } \\
\leftarrow\end{array}$ & $\begin{array}{c}\text { Contemporary Macedonian } \\
\text { Современ македонски } \\
\text { Современный македонский } \\
\text { язык } \\
\rightarrow\end{array}$ & $\begin{array}{c}\text { English } \\
\text { Англиски } \\
\text { Англиский } \\
\rightarrow\end{array}$ & $\begin{array}{c}\text { Russian } \\
\text { Руски } \\
\text { Русский язык } \\
\rightarrow\end{array}$ \\
\hline 326. & & аЦНоТееС & $\begin{array}{c}\text { Сетонци (жители на } \\
\text { Долен Египет) - оние на } \\
\text { кои врховен бог им бил } \\
\text { египетскиот бог Сет }\end{array}$ & $\begin{array}{c}\text { Sethonians (citizens of } \\
\text { Lower Egypt) - those ones } \\
\text { that worship Seth as a } \\
\text { Supreme God }\end{array}$ & $\begin{array}{c}\text { Сетонци (народ } \\
\text { Долного Египта)- } \\
\text { тем каму верховний } \\
\text { Бог был египетский } \\
\text { бог Сет }\end{array}$ \\
\hline 327. & 7 & $\mathrm{~A}$ eeC aH & На сѐ е врховна (прва) & $\begin{array}{c}\text { Is Supreme Goddess of } \\
\text { everything }\end{array}$ & На все верховная \\
\hline 328. & & еВ иКееС аН & На секој мајстор & Of every workman & Каждому мастер \\
\hline 329. & & ьВ eeC aH & На сѐ врв - победа & $\begin{array}{l}\text { Peak of everything } \\
\text { (everybody) - victory }\end{array}$ & Победа \\
\hline 330. & & $\mathrm{H}$ eeC $\mathrm{aH}$ & На сите ни (нам) & To all of us & На всех нас \\
\hline 331. & & И (врП) Н еeC aН & На сите ни (нам) прв & First among all of us & Первий между нас \\
\hline 332. & & еНИ Н еeC aH & На сите ни (нам) туѓинци & To all of us (are) foreigners & $\begin{array}{c}\text { На всех нас они } \\
\text { чужденцы }\end{array}$ \\
\hline 333. & & eHaЃeeC & Сите војници & All soldiers & Все военые \\
\hline 334. & & аЃу Љ аЦаЛееС & $\begin{array}{c}\text { Сите лавови војници - } \\
\text { македонски војници }\end{array}$ & $\begin{array}{l}\text { All lions soldiers - } \\
\text { Macedonian soldiers }\end{array}$ & $\begin{array}{c}\text { Все льви военые - } \\
\text { македонские военые }\end{array}$ \\
\hline 335. & 3 & oоЏ eeC aH & На сите животни & To all animals & На всех животних \\
\hline
\end{tabular}




\begin{tabular}{|c|c|c|c|c|c|}
\hline & $\begin{array}{l}\text { The original } \\
\text { Оригинал } \\
\text { Оригинал }\end{array}$ & $\begin{array}{c}\text { Cyrillic transcription } \\
\text { Кирилична транскрипција } \\
\text { Кириличная транскрипция } \\
\leftarrow \\
\leftarrow\end{array}$ & $\begin{array}{c}\text { Contemporary Macedonian } \\
\text { Современ македонски } \\
\text { Современный македонский } \\
\text { язык } \\
\rightarrow\end{array}$ & $\begin{array}{c}\text { English } \\
\text { Англиски } \\
\text { Англиский } \\
\rightarrow\end{array}$ & $\begin{array}{c}\text { Russian } \\
\text { Руски } \\
\text { Русский язык } \\
\rightarrow\end{array}$ \\
\hline \multicolumn{6}{|c|}{$\mathbf{T}$} \\
\hline 336. & 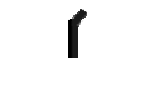 & oT & Показна заменка; Член & Pronoun; Definite & $\begin{array}{l}\text { Местоимение; } \\
\text { Определенные }\end{array}$ \\
\hline 337. & أ, & bJoT & Toj & $\mathrm{He}$ & Он \\
\hline 338. & Pr & eJoT & Toa & It & Она \\
\hline 339. & If & ИоТ & Тие & They & Они \\
\hline 340. & $<f$ & eBoT & Тие Оние & Those & Они \\
\hline \multicolumn{6}{|c|}{ Ḱ } \\
\hline 341. & $\angle$ & aḰ & Шеф; Ḱaja & Head; Chief; Main & Руководитеь; Шеф \\
\hline 342. & $\boldsymbol{T}$ & ьЈеḰ & Дека е & That it is & Который есть \\
\hline \multicolumn{6}{|c|}{$\mathbf{y}$} \\
\hline 343. & 12 & oMY & Умот & The mind & $\mathrm{y}_{\mathrm{M}}$ \\
\hline 344. & 21 & ee3y & Устие & Delta (of a river) & Устье \\
\hline 345. & 2 & еe3У аН & На устие & At the delta (of a river) & На устье \\
\hline
\end{tabular}




\begin{tabular}{|c|c|c|c|c|c|}
\hline & $\begin{array}{l}\text { The original } \\
\text { Оригинал } \\
\text { Оригинал }\end{array}$ & $\begin{array}{c}\text { Cyrillic transcription } \\
\text { Кирилична транскрипција } \\
\text { Кириличная транскрипция } \\
\leftarrow\end{array}$ & $\begin{array}{c}\text { Contemporary Macedonian } \\
\text { Современ македонски } \\
\text { Современный македонский } \\
\text { язык } \\
\rightarrow \\
\end{array}$ & $\begin{array}{c}\text { English } \\
\text { Англиски } \\
\text { Англиский } \\
\rightarrow \\
\end{array}$ & $\begin{array}{c}\text { Russian } \\
\text { Руски } \\
\text { Русский язык } \\
\rightarrow \\
\end{array}$ \\
\hline \multicolumn{6}{|c|}{$\Phi$} \\
\hline . & & & & & \\
\hline \multicolumn{6}{|c|}{$\mathbf{X}$} \\
\hline 346. & $\downarrow$ & ooX & Писменост & Literacy & Писменость \\
\hline \multicolumn{6}{|c|}{ Ц } \\
\hline 347. & $\boldsymbol{V}$ & аЦ & Товар житарица & Load of grain & $\begin{array}{c}\text { Отелотвореность, } \\
\text { воплощение, }\end{array}$ \\
\hline 348. & l & оТаЦ & $\begin{array}{c}\text { Товарот житарица; } \\
\text { Тврдиот }\end{array}$ & load of grain; The hard & Твердый \\
\hline 349. & & oTeeS оТаЦ недЕ & $\begin{array}{c}\text { Данок што се плаќал во } \\
\text { Египет во тој период од } \\
\text { имоти со житарици и } \\
\text { изнесувал еден товар со } \\
\text { жито од } 1 \text { зора (мерка за } \\
\text { површина која приближ- } \\
\text { но изнесувала } 1 \text { акра, } \\
\text { односно околу } 4000 \mathrm{~m}^{2} \text { ) }\end{array}$ & $\begin{array}{l}\text { The tax that was payed in } \\
\text { the Ancient Egypt in the } \\
\text { Ptolemaic period in the } \\
\text { quantity of } 1 \text { load of grain } \\
\text { from } 1 \text { aurora (measure for } \\
\text { land with a value of } 1 \text { acre, } \\
\text { or around } 4000 \mathrm{~m}^{2} \text { ) }\end{array}$ & $\begin{array}{c}\text { Налог, который опла- } \\
\text { чивался в Древнем } \\
\text { Египте в период Пто- } \\
\text { лемеев в количестве } \\
\text { одной нагрузки зерна } \\
\text { с 1-ого сияния (земе- } \\
\text { льний размер со зна- } \\
\text { чением } 1 \text { акр, или } \\
\left.\text { около } 4000 \mathrm{~m}^{2}\right)\end{array}$ \\
\hline
\end{tabular}




\begin{tabular}{|c|c|c|c|c|c|}
\hline & $\begin{array}{l}\text { The original } \\
\text { Оригинал } \\
\text { Оригинал }\end{array}$ & $\begin{array}{c}\text { Cyrillic transcription } \\
\text { Кирилична транскрипција } \\
\text { Кириличная транскрипция } \\
\leftarrow\end{array}$ & $\begin{array}{c}\text { Contemporary Macedonian } \\
\text { Современ македонски } \\
\text { Современный македонский } \\
\text { язык } \\
\rightarrow\end{array}$ & $\begin{array}{c}\text { English } \\
\text { Англиски } \\
\text { Англиский } \\
\rightarrow\end{array}$ & $\begin{array}{c}\text { Russian } \\
\text { Руски } \\
\text { Русский язык } \\
\rightarrow\end{array}$ \\
\hline 350. & 7 & еец & Ценет & Esteemed; Valuable & Уваеный \\
\hline \multicolumn{6}{|c|}{$\mathbf{Y}$} \\
\hline 351. & V & $\mathrm{a} \Psi$ & Сончев зрак & Sun ray & Солнечний лучь \\
\hline \multicolumn{6}{|c|}{$\bigsqcup$} \\
\hline 352. & 4 & ооЏ & Животно & Animal & Животное \\
\hline \multicolumn{6}{|c|}{ Ш } \\
\hline 353. & ב & ьШ & Свештенство & Priesthood & Свещенство \\
\hline 354. & & А ьШ ан & $\begin{array}{c}\text { На свештенство врховна } \\
\text { (прва) }\end{array}$ & $\begin{array}{l}\text { The Supreme of priests } \\
\text { (first priest) }\end{array}$ & $\begin{array}{l}\text { Верховная } \\
\text { священства }\end{array}$ \\
\hline 355. & & еВ ьШ аН & $\begin{array}{c}\text { На свештенство градба } \\
\text { (храм) }\end{array}$ & $\begin{array}{l}\text { Construction for } \\
\text { priesthood (temple) }\end{array}$ & $\begin{array}{c}\text { Строитество для } \\
\text { священства (храм) }\end{array}$ \\
\hline 356. & & ИеВ ьШ аН & $\begin{array}{c}\text { На свештенство градби } \\
\text { (храмови) }\end{array}$ & $\begin{array}{l}\text { Constructions for } \\
\text { priesthood (temples) }\end{array}$ & $\begin{array}{c}\text { Строительства для } \\
\text { священства } \\
\text { (храмов) }\end{array}$ \\
\hline
\end{tabular}




\begin{tabular}{|c|c|c|c|c|c|}
\hline & $\begin{array}{l}\text { The original } \\
\text { Оригинал } \\
\text { Оригинал }\end{array}$ & $\begin{array}{c}\text { Cyrillic transcription } \\
\text { Кирилична транскрипција } \\
\text { Кириличная транскрипция } \\
\leftarrow\end{array}$ & $\begin{array}{c}\text { Contemporary Macedonian } \\
\text { Современ македонски } \\
\text { Современный македонский } \\
\text { язык } \\
\rightarrow \\
\end{array}$ & $\begin{array}{c}\text { English } \\
\text { Англиски } \\
\text { Англиский } \\
\rightarrow \\
\end{array}$ & $\begin{array}{c}\text { Russian } \\
\text { Руски } \\
\text { Русский язык } \\
\rightarrow \\
\end{array}$ \\
\hline 357. & & В ИеВ ьШ аН & $\begin{array}{c}\text { На свештенство } \\
\text { градбиве (храмовиве) }\end{array}$ & $\begin{array}{l}\text { These constructions for } \\
\text { priesthood (these temples) }\end{array}$ & $\begin{array}{c}\text { Строительства для } \\
\text { священства (храмы) }\end{array}$ \\
\hline 358. & & НеВаН ИеВ ьШ аН & Во храмови направен & Made in temples & Сделан в храмах \\
\hline 359. & & е3 еВеВ ИеВьШ аН & Храмови државни светли & Temples of state bright & Сделано священством \\
\hline 360. & & НеВаН ьШ аН & $\begin{array}{c}\text { Од свештенство } \\
\text { направен }\end{array}$ & Made by priesthood & $\begin{array}{c}\text { Государственние } \\
\text { светлые храмы }\end{array}$ \\
\hline 361. & & еВоРьШ & Шариве & These decorations & Расцветки \\
\hline 362. & & оМеШ & Свештеник & Priest & Священик \\
\hline 363. & & ИоМеШ & Свештеници & Priests & Священики \\
\hline 364. & & Н оМеШ & Свештеник ни & Priest of ours & Священик наш \\
\hline 365. & & иШ & Камен; Икона & Stone; Effigy & Камень; Икона \\
\hline 366. & $\mathbf{c}$ & ИиШ & Камења; Икони & Stones; Effigies & Камни; Иконы \\
\hline 367. & 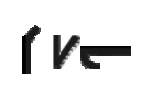 & оТаЦиШ & $\begin{array}{c}\text { Камен тврдиот } \\
\text { (црн гранит) }\end{array}$ & $\begin{array}{l}\text { The hard stone } \\
\text { (granite) }\end{array}$ & $\begin{array}{c}\text { Твердыйй камень } \\
\text { (черный гранит) }\end{array}$ \\
\hline
\end{tabular}




\begin{tabular}{|c|c|c|c|c|c|}
\hline & $\begin{array}{c}\text { The original } \\
\text { Оригинал } \\
\text { Оригинал }\end{array}$ & $\begin{array}{c}\text { Cyrillic transcription } \\
\text { Кирилична транскрипција } \\
\text { Кириличная транскрипция } \\
\leftarrow\end{array}$ & $\begin{array}{c}\text { Contemporary Macedonian } \\
\text { Современ македонски } \\
\text { Современный македонский } \\
\text { язык } \\
\rightarrow\end{array}$ & $\begin{array}{c}\text { English } \\
\text { Англиски } \\
\text { Англиский } \\
\rightarrow\end{array}$ & $\begin{array}{c}\text { Russian } \\
\text { Руски } \\
\text { Русский язык } \\
\rightarrow\end{array}$ \\
\hline 368. & & аЌиШаН & На камен ќаја (шеф) & Head (chief) of stone & Государь камня \\
\hline 369. & & ьЈ еВиШ аН & На камен мајстор ѐ & He is a stone - mason & Мастер камня \\
\hline 370. & & НеВаН иШ аН & На камен направен & Made on stone & На камень сделано \\
\hline 371. & & еЗеВаН иШ аН & $\begin{array}{c}\text { На камен навезе } \\
\text { (напише) }\end{array}$ & Embroider (write) on stone & На камень написать \\
\hline 372. & & НеЗеВаН иШ аН & $\begin{array}{c}\text { На камен навезен } \\
\text { (напишан) }\end{array}$ & $\begin{array}{l}\text { Embroidered (written) on } \\
\text { stone }\end{array}$ & На камень написать \\
\hline 373. & $\boldsymbol{c}$ & ееШ & $?$ & $?$ & $?$ \\
\hline 374. & & eeШ A aH & Наше & Our & Наше \\
\hline 375. & & НиаК оМИ ееШаН & Наш непријател & Our enemy & Наш соперник \\
\hline 376. & & АИ ееШаН аН & На наша земја & On our land & На нашей земле \\
\hline 377. & & аЧеМ ееШаН & Наши манџи & Our meals & Наши блюда \\
\hline 378. & & eS ооГоБ оВееШаН & Нашиов Бог Se & Our God Dze & Бог наш Дзе \\
\hline 379. & 2 & ееТШ & Штитеничка & She-protégé & Защиткица \\
\hline
\end{tabular}




\begin{tabular}{|c|c|c|c|c|c|}
\hline & $\begin{array}{l}\text { The original } \\
\text { Оригинал } \\
\text { Оригинал }\end{array}$ & $\begin{array}{c}\text { Cyrillic transcription } \\
\text { Кирилична транскрипција } \\
\text { Кириличная транскрипция } \\
\leftarrow\end{array}$ & $\begin{array}{c}\text { Contemporary Macedonian } \\
\text { Современ македонски } \\
\text { Современный македонский } \\
\text { язык } \\
\rightarrow \\
\end{array}$ & $\begin{array}{l}\text { English } \\
\text { Англиски } \\
\text { Англиский } \\
\rightarrow \\
\end{array}$ & $\begin{array}{c}\text { Russian } \\
\text { Руски } \\
\text { Русский язык } \\
\rightarrow \\
\end{array}$ \\
\hline 380. & $\int d x$ & отЛ НееТШаН & Секое лето & Each summer & Каждое лето \\
\hline \multicolumn{6}{|c|}{$\mathbf{b}$} \\
\hline 381. & $\mathbf{u}$ & $\mathrm{b}$ & Почва & Soil & Почва \\
\hline 382. & $\lambda$ & аЌиШ аН Л оТоП ь & $\begin{array}{c}\text { Земниот град, на мај- } \\
\text { сторите на каменот } \\
\text { (каменоресците) } \\
\text { (Птолемаида - родниот } \\
\text { град на Птоломеј Сотер } \\
\text { основач на династијата } \\
\text { Птоломеи) }\end{array}$ & $\begin{array}{l}\text { The city of soil } \\
\text { (Ptolemaida - birth city } \\
\text { of Soter Ptolemy, founder } \\
\text { of Ptolemaic Dynasty) }\end{array}$ & $\begin{array}{c}\text { На почве город } \\
\text { (Птолемаида - } \\
\text { родной город Птоло- } \\
\text { мея Сотери основа- } \\
\text { телем династии } \\
\text { Птоломея; } \\
\text { Птоломеев) }\end{array}$ \\
\hline \multicolumn{6}{|c|}{00} \\
\hline 383. & ก & $\mathrm{OO}$ & $\begin{array}{c}\text { Врховен (небесен); } \\
\text { владетел }\end{array}$ & Supreme (heavenly); Lord & $\begin{array}{c}\text { Вверховный } \\
\text { (небесный), } \\
\text { владетель }\end{array}$ \\
\hline 384. & & AeeS aH OO & $\begin{array}{c}\text { Господар на првиот } \\
\text { сончев зрак (на зората) }\end{array}$ & $\begin{array}{l}\text { Lord of the first sun light } \\
\text { (of dawn) }\end{array}$ & $\begin{array}{c}\text { Госудрь первого } \\
\text { солнечного света } \\
\text { (зоря) }\end{array}$ \\
\hline
\end{tabular}




\begin{tabular}{|c|c|c|c|c|c|}
\hline & $\begin{array}{l}\text { The original } \\
\text { Оригинал } \\
\text { Оригинал }\end{array}$ & $\begin{array}{c}\text { Cyrillic transcription } \\
\text { Кирилична транскрипција } \\
\text { Кириличная транскрипция } \\
\leftarrow \\
\end{array}$ & $\begin{array}{c}\text { Contemporary Macedonian } \\
\text { Современ македонски } \\
\text { Современный македонский } \\
\text { язык } \\
\rightarrow \\
\end{array}$ & $\begin{array}{l}\text { English } \\
\text { Англиски } \\
\text { Англиский } \\
\quad \rightarrow\end{array}$ & $\begin{array}{l}\text { Russian } \\
\text { Руски } \\
\text { Русский язык } \\
\rightarrow \\
\end{array}$ \\
\hline 385. & $\frac{17}{11}$ & $\begin{array}{c}\text { оМеШ врП AeeS aH } \\
\text { ОО } \\
\text { АеДоМ аН аЦед }\end{array}$ & $\begin{array}{c}\text { Господар на зората; Прв } \\
\text { свештеник на децата на } \\
\text { Голема Мајка Божица } \\
\text { врховна (Прв свештеник } \\
\text { на Македонците) }\end{array}$ & $\begin{array}{l}\text { Lord of the first sun light; } \\
\text { First (Arch) priest of chil- } \\
\text { dren of (the) Great Mother } \\
\text { (First priest of } \\
\text { Macedonians) }\end{array}$ & $\begin{array}{c}\text { Государь зоры; } \\
\text { Первий священий } \\
\text { Великой Матери } \\
\text { богини верховной } \\
\text { (Первый сящений } \\
\text { ариепископ } \\
\text { Македонцев) }\end{array}$ \\
\hline \multicolumn{6}{|c|}{$\begin{array}{c}\text { Gods of the Ancient Macedonians } \\
\text { Богови на древните Македонци } \\
\text { Боги древних Македонцев }\end{array}$} \\
\hline 386. & & оМ ооГоБ & Богови на Голема Мајка & $\begin{array}{l}\text { Gods of (the) Great } \\
\text { Mother }\end{array}$ & $\begin{array}{l}\text { Боги Большой } \\
\text { Матери }\end{array}$ \\
\hline 387. & & ооВ ооГоБ & $\begin{array}{c}\text { Богот Воо - Богот Сонце } \\
\text { творец на Универзумот }\end{array}$ & $\begin{array}{l}\text { God Voo - God of the Sun } \\
\text { Creator of the Universe }\end{array}$ & Бог Ве - Бог масеров \\
\hline 388. & & eS ооГоБ & $\begin{array}{c}\text { Богот } \mathrm{Se} ; \text { Големото Око } \\
- \text { Врховен Бог }\end{array}$ & God Dze - Supreme God & $\begin{array}{c}\text { Бог Дзе - Верховный } \\
\text { Бог }\end{array}$ \\
\hline 389. & & $\begin{array}{l}\text { еВееЗаН ИоМ } \\
\text { ИоТЛ ооГоБ }\end{array}$ & $\begin{array}{c}\text { Моите го нарекуваат } \\
\text { Бог на летата }\end{array}$ & $\begin{array}{l}\text { We call him } \\
\text { God of summers }\end{array}$ & $\begin{array}{l}\text { Мои называют его } \\
\text { Богом лета }\end{array}$ \\
\hline
\end{tabular}




\begin{tabular}{|c|c|c|c|c|c|}
\hline & $\begin{array}{l}\text { The original } \\
\text { Оригинал } \\
\text { Оригинал }\end{array}$ & $\begin{array}{c}\text { Cyrillic transcription } \\
\text { Кирилична транскрипција } \\
\text { Кириличная транскрипция } \\
\leftarrow\end{array}$ & $\begin{array}{c}\text { Contemporary Macedonian } \\
\text { Современ македонски } \\
\text { Современный македонский } \\
\text { язык } \\
\rightarrow\end{array}$ & $\begin{array}{l}\text { English } \\
\text { Англиски } \\
\text { Англиский } \\
\rightarrow\end{array}$ & $\begin{array}{c}\text { Russian } \\
\text { Руски } \\
\text { Русский язык } \\
\rightarrow\end{array}$ \\
\hline 390. & $\mathbf{s}$ & eeS ооГоБ & $\begin{array}{c}\text { Богот See - Божица на } \\
\text { сончева светлина }\end{array}$ & $\begin{array}{c}\text { Goddess Dzee - Goddess } \\
\text { of the sun light }\end{array}$ & $\begin{array}{l}\text { Бог Дзее - Богиня } \\
\text { солнечного света }\end{array}$ \\
\hline 391. & & е3 ооГоБ & $\begin{array}{c}\text { Богот Зе - Бог младо } \\
\text { сонце (во Египет тоа е } \\
\text { Богот Пта; кај Данајците } \\
\text { Хорус) }\end{array}$ & $\begin{array}{l}\text { God Ze - God of young } \\
\text { sun (in Egypt God Ptah; } \\
\text { among Danaans Horus) }\end{array}$ & $\begin{array}{c}\text { Бог Зе - Бог молодое } \\
\text { солнце (в Египете это } \\
\text { Бог Пта, у Данайцев } \\
\text { Хорус) }\end{array}$ \\
\hline 392. & & еeЗ ооГоБ & $\begin{array}{c}\text { Богот Зее - Божица на } \\
\text { месечева (ладна) } \\
\text { светлина }\end{array}$ & $\begin{array}{l}\text { Goddess Zee - Goddess of } \\
\text { the moon (cold) light }\end{array}$ & $\begin{array}{c}\text { Бог Зее - Богиня } \\
\text { луного (холодого) } \\
\text { света }\end{array}$ \\
\hline 393. & & ееЖ ооГоБ & $\begin{array}{c}\text { Богот Жее - Божица на } \\
\text { животната енергија }\end{array}$ & $\begin{array}{c}\text { Goddess Zhee - Goddess } \\
\text { of life energy }\end{array}$ & $\begin{array}{l}\text { Бог Жее - Богиня } \\
\text { жизненой енергии }\end{array}$ \\
\hline 394. & & еВ ооГоБ & $\begin{array}{c}\text { Богот Ве - Бог на } \\
\text { мајсторите }\end{array}$ & $\begin{array}{c}\text { God Ve - God of workmen } \\
\text { (constructions) }\end{array}$ & Бог Ве - Бог масеров \\
\hline 395. & 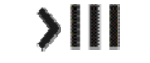 & оВ ооГоБ & Богот Во - Бог на водата & God Vo - God of water & Бог Во - Бог воды \\
\hline 396. & & ооХ ооГоБ & $\begin{array}{c}\text { Богот Хоо - Божица на } \\
\text { писменоста }\end{array}$ & $\begin{array}{c}\text { Goddess Hoo - Goddess of } \\
\text { literacy }\end{array}$ & $\begin{array}{c}\text { Бог Хоо - Богиня } \\
\text { писмености }\end{array}$ \\
\hline
\end{tabular}




\begin{tabular}{|c|c|c|c|c|c|}
\hline & $\begin{array}{c}\text { The original } \\
\text { Оригинал } \\
\text { Оригинал }\end{array}$ & $\begin{array}{c}\text { Cyrillic transcription } \\
\text { Кирилична транскрипција } \\
\text { Кириличная транскрипция } \\
\leftarrow\end{array}$ & $\begin{array}{c}\text { Contemporary Macedonian } \\
\text { Современ македонски } \\
\text { Современный македонский } \\
\text { язык } \\
\rightarrow\end{array}$ & $\begin{array}{l}\text { English } \\
\text { Англиски } \\
\text { Англиский } \\
\rightarrow\end{array}$ & $\begin{array}{l}\text { Russian } \\
\text { Руски } \\
\text { Русский язык } \\
\rightarrow\end{array}$ \\
\hline 397. & & ооЏ ооГоБ & $\begin{array}{c}\text { Богот Џоо - Бог на } \\
\text { животните, заштитник } \\
\text { (патрон) на сите } \\
\text { празници }\end{array}$ & $\begin{array}{l}\text { God Dzhoo - } \\
\text { God of animals }\end{array}$ & $\begin{array}{c}\text { Бог Джоо - Бог } \\
\text { животных, защитник } \\
\text { (патрон) всех } \\
\text { праздников }\end{array}$ \\
\hline 398. & & аК ооГоБ & $\begin{array}{c}\text { Богот Ка - Бог на } \\
\text { здравјето; врховен бог на } \\
\text { Горна Македонија }\end{array}$ & $\begin{array}{c}\text { God Ka - God (dragon) } \\
\text { of health }\end{array}$ & $\begin{array}{c}\text { Бог Ка - Бог здо- } \\
\text { ровья, верховний бог } \\
\text { Вверхней Македонии }\end{array}$ \\
\hline 399. & & аС ооГоБ & $\begin{array}{c}\text { Богот Са - Бог } \\
\text { на земјоделството } \\
\text { (садењето) }\end{array}$ & $\begin{array}{c}\text { God } \mathrm{Sa}-\text { God of agricul- } \\
\text { ture }\end{array}$ & $\begin{array}{c}\text { Бог Са - Бог } \\
\text { земледелия }\end{array}$ \\
\hline 400. & & аЃ ооГоБ & Богот Ѓа - Бог на војната & God GJa - God of war & Бог Гя - Бог войны \\
\hline 401. & & (жУ) ајим3 ооГоБ & Богот Уж - Богот Змија & God Uzh - God Snake & Бог Уж - Бог змия \\
\hline \multicolumn{6}{|c|}{$\begin{array}{l}\text { Gods of the Ancient Egyptians } \\
\text { Богови на древните Египќани } \\
\text { Боги древних Египцев }\end{array}$} \\
\hline 402. & & НуСА аН Е ооГоБ & $\begin{array}{c}\text { Богот на Асуан - } \\
\text { Врховен Бог на Горен } \\
\text { Египет }\end{array}$ & $\begin{array}{c}\text { God of Aswan - the Su- } \\
\text { preme God of Upper Egypt }\end{array}$ & $\begin{array}{c}\text { Бог Асуан - } \\
\text { Верховный бог } \\
\text { Горного Египта }\end{array}$ \\
\hline
\end{tabular}




\begin{tabular}{|c|c|c|c|c|c|}
\hline & $\begin{array}{l}\text { The original } \\
\text { Оригинал } \\
\text { Оригинал }\end{array}$ & $\begin{array}{c}\text { Cyrillic transcription } \\
\text { Кирилична транскрипција } \\
\text { Кириличная транскрипция } \\
\leftarrow\end{array}$ & $\begin{array}{c}\text { Contemporary Macedonian } \\
\text { Современ македонски } \\
\text { Современный македонский } \\
\text { язык } \\
\rightarrow\end{array}$ & $\begin{array}{l}\text { English } \\
\text { Англиски } \\
\text { Англиский } \\
\rightarrow\end{array}$ & $\begin{array}{c}\text { Russian } \\
\text { Руски } \\
\text { Русский язык } \\
\rightarrow\end{array}$ \\
\hline 403. & & ееЗУ аН О ооГоБ & $\begin{array}{c}\text { Богот на устието } \\
\text { (на делтата на Нил) - } \\
\text { Врховен Бог на Долен } \\
\text { Египет (Сет) }\end{array}$ & $\begin{array}{l}\text { God of the Nile Delta - } \\
\text { Supreme God of Lower } \\
\text { Egypt (Seth) }\end{array}$ & $\begin{array}{c}\text { Бог дельты Нила - } \\
\text { Верховный бог } \\
\text { Нижнего Египта } \\
\text { (Сет) }\end{array}$ \\
\hline 404. & & ооГоБ аЦеНаНА & Египетски Бог Ананеца & $\begin{array}{l}\text { Egyptian God Ananetsa } \\
\text { (Greek name - Osiris) }\end{array}$ & Озирис \\
\hline 405. & $V_{y}$ & аЧеНаНА & $\begin{array}{c}\text { Египетска Божица } \\
\text { Ананеча }\end{array}$ & $\begin{array}{l}\text { Egyptian Goddess Ananet- } \\
\text { scha (Greek name - Isis) }\end{array}$ & Изис \\
\hline \multicolumn{6}{|c|}{$\begin{array}{c}\text { God of the Ancient Jews } \\
\text { Бог на Евреите } \\
\text { Боги Евреев }\end{array}$} \\
\hline 406. & & $\begin{array}{c}\text { ооГоБ оТ } \\
\text { ИНаН БТ аН ооЈ }\end{array}$ & $\begin{array}{c}\text { Тој Бог Јоо на Тнани } \\
\text { (зборот Тнани на } \\
\text { Хебрејски значи Ветена } \\
\text { Земја - Израел) }\end{array}$ & $\begin{array}{l}\text { That God Joo of Tnani } \\
\text { (Promised Land - Israel) }\end{array}$ & $\begin{array}{c}\text { Это Бог Йоо Танинов } \\
\text { (Танин на Ивриде } \\
\text { означает Земля } \\
\text { Обетованная - } \\
\text { Израель) }\end{array}$ \\
\hline
\end{tabular}




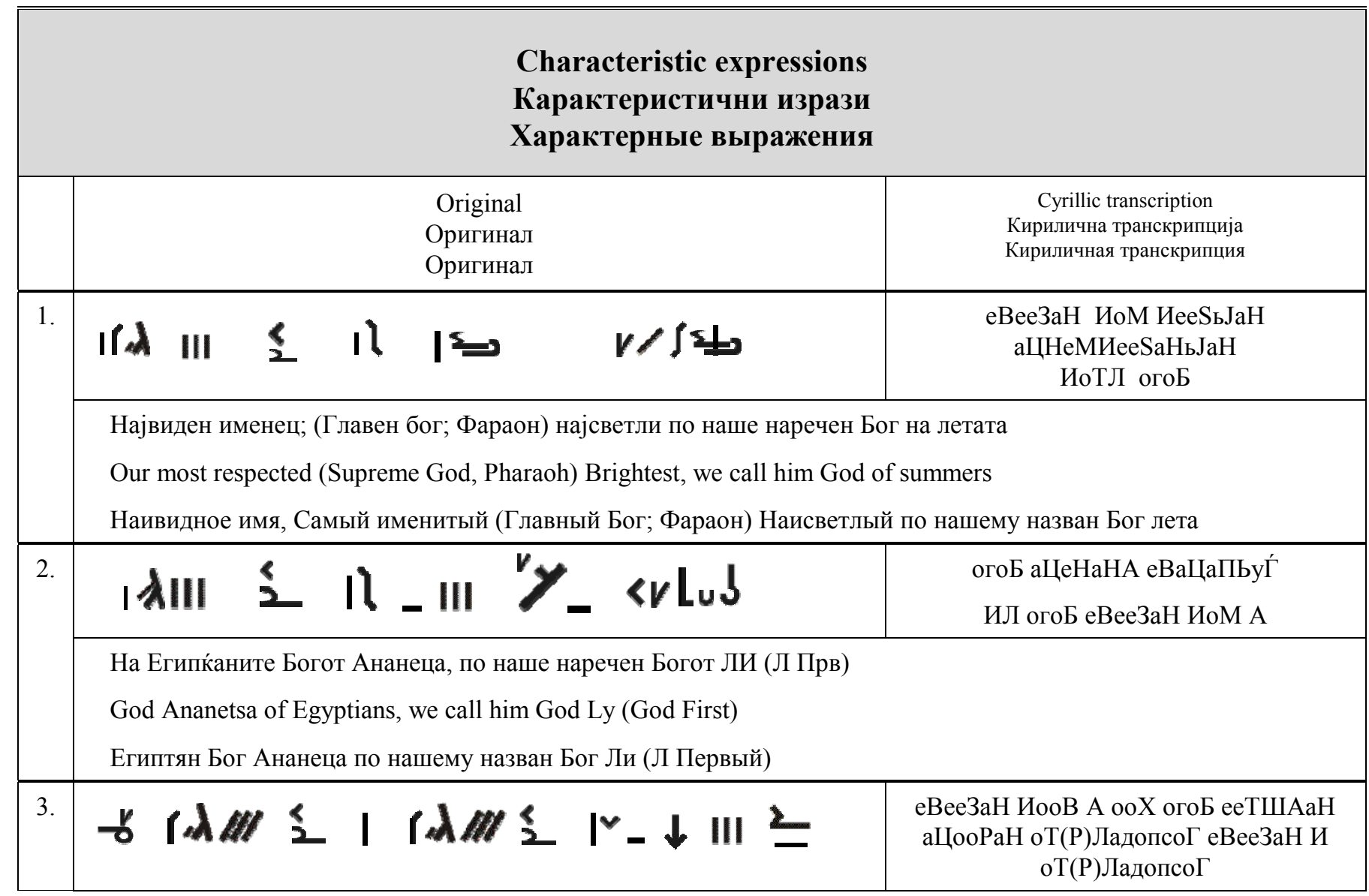




\begin{tabular}{|c|c|c|}
\hline & \multicolumn{2}{|c|}{$\begin{array}{l}\text { Нашата Божица Хоо, а по Ваше Господар и по Ваше Господар на Свет запис } \\
\text { Our Goddess Hoo, you call him Master and you call him Master of Holly (Sacred) Text } \\
\text { Наша Богиня Хоо, а по Вашему Господар/Хозяин и по Вашему назван Господар Святой записи }\end{array}$} \\
\hline 4. & 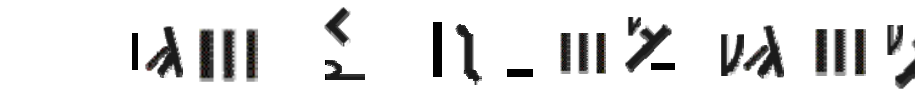 & $\begin{array}{c}\text { А огоБ аЦеНаНА аЧЛ огоБ аЧеНаНА } \\
\text { ИЛ огоБ еВееЗаН ИоМ }\end{array}$ \\
\hline & $\begin{array}{l}\text { Ананеча Божица на Сончев зрак, Ананеца Богот, а по наше нг } \\
\text { Ananecha, Godess of Sun ray, Ananetsa God, we call him God Ly } \\
\text { Ананеча Богиня Солнечного луча, Ананеца Бог, а по нашему }\end{array}$ & $\begin{array}{l}\text { гот ЛИ (Л Прв) } \\
\text { г ЛИ (Л Первый) }\end{array}$ \\
\hline \multirow[t]{2}{*}{5.} & $n$ & оТеС оБеН аН ОО ооВ огоБ \\
\hline & $\begin{array}{l}\text { Богот Воо Господар на небо сето } \\
\text { God Voo Lord of all sky } \\
\text { Бог Воо Господар на Небе всем }\end{array}$ & \\
\hline \multirow[t]{2}{*}{6.} & 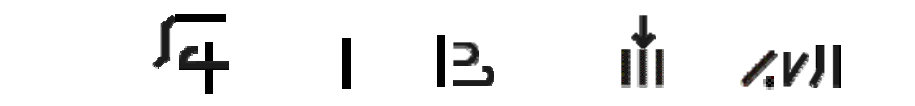 & $\begin{array}{c}\text { еМИееШаНаН иврП ИоБьЈаН } \\
\text { ооХогоБаН аНаЦед }\end{array}$ \\
\hline & $\begin{array}{l}\text { Децана на Божицата Хоо, најдобри души, први на наше име } \\
\text { Children of Goddess Hoo, best souls, first ones among us } \\
\text { Дети те Богини Хоо, наилущие души, первые нашего имени }\end{array}$ & \\
\hline 7. & $v / L \mid V l u b \quad \pi$ & $\begin{array}{c}\text { аЦНоТееС И аЦаПьуѓ И АеДоМаН } \\
\text { аЦед }\end{array}$ \\
\hline
\end{tabular}




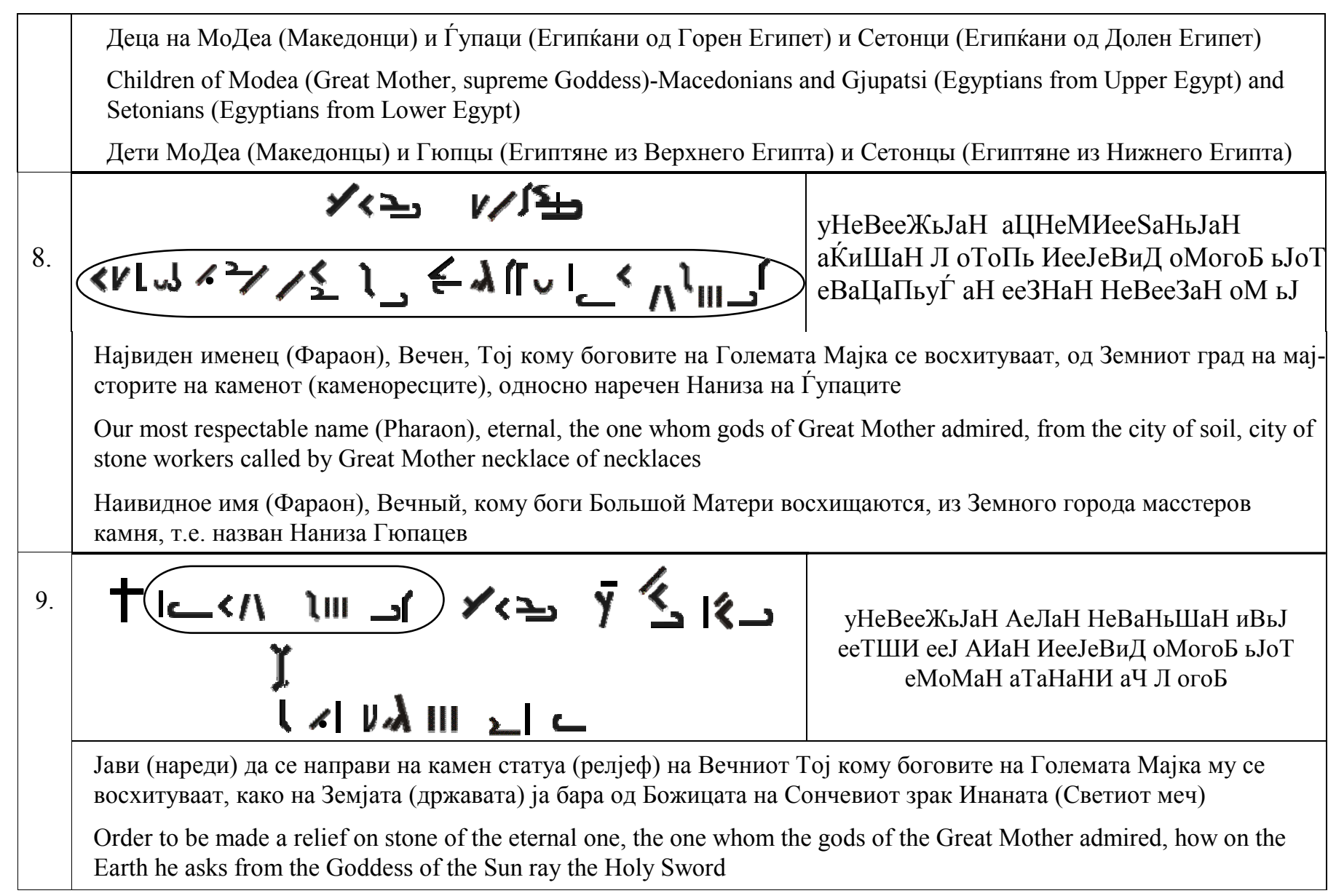


Явил (Повелел) сделать из камня статую (рельеф) Вечному Тому кому боги Большой Матери восхищаются, как

Страна требует от Богини Солнечного луча Инаната (Святой меч)

10 .

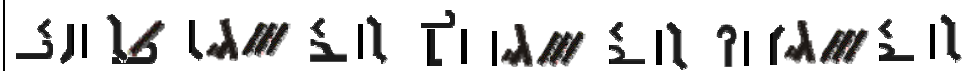$$
-1 v-\% ? v 19 \%
$$

еВееЗаН ИоМ еНеЗеВаНиШаН едьБ иВьЈ И ИЛадопсоГ еВееЗаН ИоМ еѓИ оТЛадопсоГ аТЛадопсоГ еВееЖаН ИоМ ьЈаПаН оТаЦ иШ ВВ аЦИеРаН еВьЈаНед аН oMoHьJaH

Јави (нареди) да биде навезено (напишано) на камен со писмата на: моите го нарекуваат на Господарот неговите Господари, потоа на мојот жив Господар и на крај на Данајците, на камен тврдиот (гранит)

Ordered to be inscribed (embroidered) on stone with the scripts of one that we call him Master of his Masters, after that with script of my live Master and at the end with the script of Danai, on the hard stone

Явил (Повелел) быть написано на камне письмами: мои называют Господара его Господари, потом моего живого Господара и в конце Данайцев, на камне твердом (на граните)

\begin{tabular}{l|l|l|}
\hline \multirow{2}{*}{11.} & еВиРаП аН ьг аН \\
\cline { 2 - 2 } \\
$\begin{array}{l}\text { На париве на Египет } \\
\text { On the money (coins) of Egypt } \\
\text { На деньгах Египта }\end{array}$
\end{tabular}




\section{CONCLUSIONS}

In this text, we present multi-lingual dictionary of the Ancient Macedono-Slavic language, based on our research results after complete reading of the middle text on the Rosetta Stone. It includes more than 400 words and expressions. Consequently, we can definitely conclude that the Ancient Macedonian language poses syllabic characteristics, in the sense that each syllable, and even each vowel, has a meaning of a complete term in today's language form. Further, in a case when the particular syllable participates in word formed from two or more syllables, each syllable keeps its initial meaning and the meaning of the word is formed jointly by the meaning of each respective syllable participating in the word. Such characteristic is partially present in the contemporary Macedonian language.

From the presented material, one can easily conclude that substantial number of words and expressions in the Ancient Macedonian language keep same sound value and same meaning in the contemporary Macedonian language, but they are also present in other Slavic languages. These facts direct us toward conclusion that the Ancient Macedonian language that we identify in the middle text on the Rosetta and Canopus Stone presents fundament (basis) for the contemporary Macedonian language, but also it is a basis for other Slavic languages. 


\title{
КОМПАРАТИВНА АНАЛИЗА НА РЕЗУЛТАТИТЕ ОД ДЕШИФРИРАЊЕТО НА СРЕДНИОТ ТЕКСТ НА КАМЕНОТ ОД РОЗЕТА
}

\author{
Томе Бошевски, Аристотел Тентов
}

\begin{abstract}
А п с т р а к т: Во овој текст е презентирана компаративна анализа на зборовите и изразите од исчитувањето на целиот среден текст на каменот од Розета, [15], со примена на методологијата што ја презентиравме во [12].

Моментално идентификувавме повеќе од 420 различни зборови и изрази коишто го задржале нивното значење во современиот или во дијалектите на современиот македонски јазик, но и во архаична или во современа форма на современите словенски јазици. Согласно со пишаниот материјал на средниот текст на каменот од Розета, идентификацијата и анализата на структурата на речениците сега треба да биде предмет на понатамошни истражувања.
\end{abstract}

Навлегувајќи подлабоко со анализите и споредувајќи ги резултатите на нашето читање на средниот текст [15], со познатите читања на древно-грчкиот текст, дадени во [4], [5], [6] и [9], можеме да заклучиме дека двата текста, таканаречениот gемойски и древно-грчкиот се ияенииични само со сояржинат̄а на наредбите на фараонот во текстовите. Секако, овие два текста се разликуваат во однос на редоследот на зборовите и во реченичката структура, што е многу логично и се очекува во сите случаи кога споредуваме два идентични текста запишани на два различни јазици, дури и денес.

Врз основа на нашите истражувања можеме да го допрецизираме овој заклучок дека Декретот на фараонот запишан на средниот текст на каменот од Розета во оригинал е запишан на јазикот на древните Македонци со писмото (знаци-

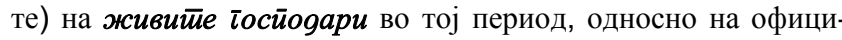
јалниот јазик и со официјалното писмо на државата со која во 196 година п.н.е. владее династијата на Птоломеите веќе повеќе од еден век. Јазикот којшто го откриваме на средниот текст на Каменот дефинитивно во себе вклучува карактеристики на словенски јазик, а многу зборови што ги идентифи- 
кувавме досега во текстот се сѐ уште присутни во моgернише словенски јазици, или во нивната архаична верзија или во современата (официјална) верзија на соодветен словенски јазик. Соодветно, во лексичка смисла, можеме овој идентификуван јазик да го дефинираме дека има многу силни словенски карактеристики. Ова станува уште поочигледно по внимателното исчитување и изучување на презентираниот повеќејазичен речник.

Клучни зборови: антички Македонци, писмо, јазик, слогова природа

Во овој текст е презентирана компаративна анализа на зборовите и изразите од исчитувањето на целиот среден текст на каменот од Розета [15], со примена на методологијата што ја презентиравме во [12].

Комплетно го завршивме читањето на текстовите напишани со т.н. демотско писмо на каменот од Розета и на каменот од Канопус, презентирани детално во [15] и [19]. Во овој момент, по исчитувањето на овие два текста, бројот на идентификуваните зборови и изрази е повеќе од 430, а интересно е што доминантен број на овие зборови и изрази го задржале своето значење во современиот македонски јазик и во неговите дијалекти, но и во голем дел од современите словенски јазици и нивните дијалекти. Врз основа на овој факт, можеме со голема доза на сигурност, да заклучиме дека овие два текста се напишани со античко-македонско писмо и на античко-македонски јазик.

Согласно со пишаниот материјал на средниот текст на каменот од Розета, идентификацијата и анализата на структурата на речениците сега треба да биде предмет на понатамошни истражувања.

Направивме детална споредба и анализа на претходните преводи на т.н. демотски и античко-грчки текст на каменот од Розета и на каменот од Канопус, презентирани во [4], [5], [6] и [9], со нашите читања на овие текстови. Според овие анализи, нашите читања на т.н. демотски текстови, наспроти преводот на соодветните антички-грчки текстови на двата камена, даваат текст којшто по содржина е ист, но со различна конструкција на речениците и редослед на зборовите. Во определени делови од споредените текстови имаме согласување на ниво на слог, а во поголем дел речениците во античко-грчкиот текст се со обратен редослед на зборовите во однос на нашиот превод на демотски текст. Мора да се напомене дека при 
читање на античко-македонските текстови добиваме многу подетални и побогати текстови во однос на постојните читања на античко-грчките текстови. Ова укажува дека текстовите напишани со античко-македонско писмо и на античко-македонско писмо се главни текстови и на двата декрети, а дека античко-грчкиот текст е само превод.

Врз основа на нашите истражувања можеме да го допрецизираме овој заклучок дека Декретот на фараонот запишан на средниот текст на каменот од Розета во оригинал е запишан на јазикот на древните Македонци со писмото (знаците) на живийе іосӣogари во тој период, односно на официјалниот јазик и со официјалното писмо на државата со која во 196 година п.н.е. владее династијата на Птолемеите повеќе од еден век. Јазикот којшто го откриваме на средниот текст на Каменот дефинитивно во себе вклучува карактеристики на словенски јазик, а многу зборови што ги идентификувавме досега во текстот се сѐ уште присутни во моgернийе словенски јазици, или во нивната архаична верзија или во современата (официјална) верзија на соодветен словенски јазик. Соодветно, во лексичка смисла, можеме овој идентификуван јазик да го дефинираме дека има многу силни словенски карактеристики. Ова станува уште поочигледно по внимателното исчитување и изучување на презентираниот повеќејазичен речник.

Во Табела 1 и 2 се прикажани идентификуваните знаци на древномакедонското писмо со нивното озвучување. Потоа е даден повеќејазичен речник.

\section{ЗАКЛУЧОК}

Во овој текст е презентиран повеќејазичен речник на древниот македонско-словенски јазик, заснован на нашите наоди по комплетното исчитување на средниот текст на каменот од Розета. Во речникот се опфатени повеќе од 400 зборови и изрази. По ова, можеме дефинитивно да заклучиме дека древниот македонски јазик има слогови карактеристики во смисла што секој слог и дури секоја самогласка има значење на цел поим или израз во денешна форма на јазикот. Понатаму, кога некој слог учествува во формирање на збор од повеќе согласки, истата го зачувува своето почетно значење, а зборот го добива заедничкото значење на сите составни слогови. Ваквата карактеристика е парцијално присутна во современиот македонски јазик.

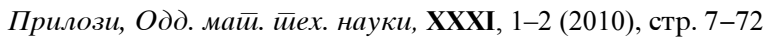


Од дадениот материјал, секој лесно може да дојде до заклучок дека значителен број на зборови и изрази од древниот македонски јазик се исти по звучност и значење и во современиот македонски јазик, но се присутни и во други современи словенски јазици. Овие факти не насочуваат кон заклучок дека древниот македонски јазик којшто го идентификувавме на средниот текст на каменот од Розета претставува основа (база) на која е изграден современиот македонски јазик, но и другите словенски јазици. 


\title{
СРАВНИТЕЛЬНЙ АНАЛИЗ РЕЗУЛЬТАТОВ ДЕШИФРОВКИ СРЕДНЕГО ТЕКСТА НА КАМНЕ ИЗ РОЗЕТЫ
}

\author{
Томе Бошевски, Аристотел Тентов
}

\begin{abstract}
А п с т р а к т: В данном тексте мы представляем часть слов и выражений, которые были нами установлены при прочтении древне-македонских текстов, написанных слоговым древнемакедонским письмом (так называемым демотическим письмом). Осованием для этого является тот факт, что презентируемые слова и выражения имеют одинаковое звуковое значение и одинаковое семантическое значение и в современном македонском литературном языке, либо в его диалектных говорах, а также в других современных славянских языках и в их диалектах. В процессе чтения текстов, написанных слоговым древне-македонским письмом и на древне-македонском языке, нами была использована методология, которую мы раньше применили и объяснили согласно пунктам [14], потом [15], а также использовали при чтении полного среднего текста на камне из Розеты [16], как и при разборке соответствующего текста на камне из Канопуса [21].

Язык, установленный нами в так называемом демотическом тексте на камне из Розеты и на камне из Канопуса безусловно содержит в себе характеристики славянских языков. Все слова, которые нам до сих пор удалось идентифицировать в указанных двух текстах, можно обнаружить во всех современных славянских языках либо в их диалектах.

Следует добавить, что для антично-македонского языка доминирующей чертой является его слоговая природа в виду того факта, что почти все основные понятия выражаются с помощью одного слога, к тому же, даже изолированные гласные обладают своим особым значением. Этот факт указывает на то, что антично-македонский язык, установленный в так называемых демотических текстах на камне из Розеты и на камне из Канопуса, быть может намного старше и возможно ведет к пра-языку, на котором все народы взаимно общались и понимали друг друга до начала строительства Вавилонской башни.
\end{abstract}

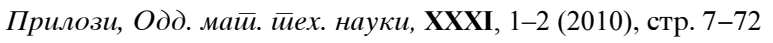


Ключевые слова: антично-македонский язык; македонскославянские характеристики; слоговая природа; пра-язык

Мы полностью закончили чтение и разборку такстов, написанных так называемым демотическим письмом на камне из Розеты и на камне из Канопуса, которые мы подробно представили в [4]. На данный момент, в результате разборки этих двух текстов число установленных слов и выражений превысило цифру 430, а при этом весьма любопытно то, что доминирующее число слов и выражений сохранили свое первычное значение в современном македонском языке и в его диалектах, а также и в большинстве славянских языках и в их диалектах. На основании этого факта, можем с большой дозой уверенности сделать заключение о том, что указанные два текста написаны антично-македонским письмом и на антично-македонском языке.

Мы провели подробный анализ предыдущих переводов так называемых демотического и антично-греческого текстов на камне из Розеты и на камне из Канопуса, с одной и с другой стороны, провели подробное сравнение их с нашим чтением этих текстов, а наши результаты были представлены в [4], [5], [6] и [9].

Согласно этим анализам, наше прочтение так называемых демотических текстов в сравнении с переводом соответствующих антично-греческих текстов на обоих камнях, устанавливает текст, который по своему содержанию одинаков, однако с различной конструкцией предложений и порядком слов. В определенных частях сравниваемых текстов обнаруживается соответствие на уровне слогов, однако в большей части предложений в антично-греческом тексте имеется обратный порядок слов по отношению к нашему переводу так называемого демотического текста. Следует напомнить, что при чтении антично-македонских текстов мы установили гораздо более подробные и более богатые тексты по отношению к существующим чтениям антично-греческих текстов. Данный факт указывает на то, что тексты, написаные антично-македонским письмом и на антично-македонском языке являются главными, первычными текстами этих двух указов, в то время как антично-греческий текст есть лишь их перевод.

Установленный антично-македонский язык согласно результатам, полученных в ходе наших исследований, отличается еще одной дополнительной характеристикой, которая его выделяет из остальных языков. А 
это - доминация в антично-македонском языке слогов, в то время как в других языках доминируют слова как их отличительная черта. Именно в антично-македонском языке основные понятия выражаются с помощью слогов, к примеру, имена богов однослоговы, а потом путем комбинировании слогов, точнее их присоединении к основному слогу в форме префиксов и/или суффиксов производятся дополнительные понятия. При этом присоединяемые слоги в качестве префиксов и/ или суффиксов сохраняют свое первычное значение. Данная характеристика указывает также на ту возможност, что антично-македонский язык, установленный нами на камне из Розеты и на камне из Канопуса, намного старше на не менее несколько тысяч лет до нашей эры.

В ходе наших исследований до сих пор нам удалось идентифицировать свыше 430 слов и выражений. Значительная часть этих слов и выражений, характерных для антично-македонского языка, мы обнаружили и в современном македонском языке и в егол диалектах, но также и во всех современных языках и/ или в их диалектах всех славянских народов. Часть этого богатого корпуса слов и выражений мы приводим на следующей таблице:

\section{ЗАКЛЮЧЕНИЕ}

В этом тексте в соответствующих частях мы показали примеры слов и выражений, которые нами были установлены в антично-македонских текстах на камне из Розеты (196 года до н.э.) и на камне из Канопуса (238 года до н.э.), оба из перида владения династии македонских царей (фараонов) в Египте, Птоломеев.

Представленные примеры указывают на две весьма важные характеристики антично-македонского славянского языка, а это:

- Данный язык облдает особенностями, котрые по сей день встречаются в современном македонском языке и в его диалектах, а также в современных языках и их диалектах всех славянских народов.

- Выявленный язык отличается также и своеобразной особенностью, которая состоит в том, что значительная часть слов, выражений и понятый являются односоговыми. Этот факт указывает на то, что данный язык на много старше периода владения Птоломеев Эгиптом, возможно на несколько тысячелетий.

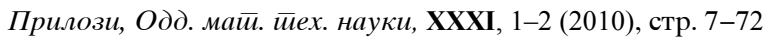


Вот в этом состоят самые важные моменты, установленные в ходе наших исследований антично-македонского языка и письма, которыми нам хотелось подлелиться на этой конференции. Все же, все это - лишь первые попытки, лишь начальные шаги в поистине огромное неиследованное пространство, жаждущего внимания многих других иследователей, таящего многие различные аспекты, котрые ждут своих первооткрывателей. 


\section{REFERENCES - ЛИТЕРАTУРА}

[1] Irena Ceklin Bačar, et al, Slovenščina - jezik na maturi: za slovenščino - jezik v četrtem letniku gimnazijskih programov: zbirka nalog za ponovitev jezikovne snovi, Ljubljana, Mladinska knjiga, 2004 (str. 90-92) ISBN 86-11-16681-7.

[2] Marja Beshter, Martina Križaj Ortar, Marija Končina, Mojca Bavdek, Mojca Poznanovič, Darnika Amrbož, Stanislava Židan, Na pragu besedila - učbenik za slovenski jezik $v 1$ letniku gimnazij, strokovnih in tehniških šol, Tiskarna Mladinska knjiga, d.d., Založba Rokus, d.o.o., 2004-godina (str. 30-34).

[3] Hendriks, The Radozda-Vevcani Dialect of Macedonian, Lisse 1976, PdR Press Publications on Macedonian 1.

[4] W. Budge, Sir, The Rosetta Stone, reprint Dover Publications, NY, USA, 1989, originally published by Religious Tract Society, London, UK, 1929.

[5] R. Parkinson, Cracking Codes: The Rosetta Stone and Decipherment, University of California Press, CA, USA, 1999.

[6] S. Quirke and C. Andrews, Rosetta Stone: Facsimile Drawing with an Introduction and Translations, Harry N. Abrams, Inc., Publishers, New York, USA, 1989.

[7] C. Thomas, Ed., Makedonika: Essays by Eugene Borza, Regina Books, Claremont, CA, USA, 1995.

[8] Encyclopedia Britanica, page 232 (Demotic Language and Writing), London, UK, 1967.

[9] Demotic Dictionary Project, Oriental Institute, University of Chicago, 2005.

[10] Г. С. Гриневич, Праславяанска писменост, Москва, 1993 година.

[11] Старославянский словар (по рукописом X-XI веков), Москва, Руский язик, 1994.

[12] T. Boshevski, A. Tentov, Tracing the Script and the Language of Ancient Macedonians, Macedonian Academy of Sciences and Arts, Contributions XXVI 2, pp. 7-122, Skopje, Republic of Macedonia, 2005.

[13] Grčko-hrvatski ili srpski rječnik, Školska knjiga, Zagreb, SFRJ, 1983.

[14] T. Boshevski, A. Tentov, Tracing the Script and the Language of Ancient Macedonians, $V^{\text {th }}$ International Conference The Origins of Europeans, Ljubljana, Slovenia, 2007.

[15] T. Boshevski, A. Tentov, Rosetta Stone - the Monument of Ancient Macedonian Pre-Slavic Script and Language, Proc. First Congress "Pre-Cyrilic Scripts and Pre-Christian Culture of Slavic Peoples”, Sanct-Petersburg, Russia, May 2008.

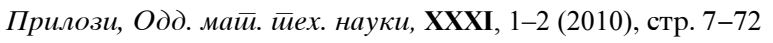


[16] http://rosetta-stone.etf.ukim.edu.mk (2007).

[17] Harald Haarmann, Universalgeschichte der Schrift, Frankfurt/Main, Computer Verlag, 1990, ISBN 3-593-34346-0.

[18] T. Boshevski, A. Tentov, Macedono-Slavic Characteristics of the Language on the Middle Text On The Rosetta Stone, Proc. Second Congress "Pre-Cyrilic Scripts and Pre-Christian Culture of Slavic Peoples", Sanct-Petersburg, Russia, May 2009.

[19] T. Boshevski, A. Tentov, Ancient-Macedonian Reading of the Demotic Text on the Canopus Stele, First Conference "Pre-Cyrilic Scripts and PreChristian Culture of Slavic Peoples", Moscow, Russia, Moscow State University of Management, 12-14 March, 2011.

Adresi:

Tome Boševski

Macedonian Academy of Sciences and Arts

Bul. Krste Misirkov, 2, P.O. Box 428

1000 Skopje, Republic of Macedonia

bosevski@feit.ukim.edu.mk

\section{Aristotel Tentov}

Ss. Cyril and Methodius University in Skopje

Faculty of Electrical Engineering and Information Technologies

Rugjer Boshkovik bb

PO Box 574, MK-1001 Skopje

Republic of Macedonia

toto@feit.ukim.edu.mk 